OPEN ACCESS

Edited by:

Andrew James Jonathan Maclntosh,

Kyoto University, Japan

Reviewed by:

Agustin Fuentes,

Princeton University, United States

Siobhan Mary Mattison,

University of New Mexico,

United States

*Correspondence:

Jennifer E. Smith

jesmith@mills.edu

Christopher R. von Rueden

cvonrued@richmond.edu

†These authors share first authorship

Specialty section:

This article was submitted to Behavioral and Evolutionary Ecology,

a section of the journal

Frontiers in Ecology and Evolution

Received: 06 March 2021

Accepted: 25 June 2021

Published: 30 July 2021

Citation:

Smith JE, von Rueden CR,

van Vugt $M$, Fichtel $C$ and

Kappeler PM (2021) An Evolutionary

Explanation for the Female Leadership

Paradox. Front. Ecol. Evol. 9:676805.

doi: 10.3389/fevo.2021.676805

\section{An Evolutionary Explanation for the Female Leadership Paradox}

\author{
Jennifer E. Smith ${ }^{1 * t}$, Christopher R. von Rueden ${ }^{2 * t}$, Mark van Vugt ${ }^{3,4}$, Claudia Fichtel $^{5}$ \\ and Peter M. Kappeler ${ }^{5,6}$
}

\begin{abstract}
${ }^{1}$ Mills College, Oakland, CA, United States, ${ }^{2}$ Jepson School of Leadership Studies, University of Richmond, Richmond, VA, United States, ${ }^{3}$ Department of Experimental and Applied Psychology, Vrije Universiteit Amsterdam, Amsterdam, Netherlands, ${ }^{4}$ Department of Politics and International Relations, University of Oxford, Oxford, United Kingdom, ${ }^{5}$ Behavioral Ecology \& Sociobiology Unit, German Primate Center, Leibniz Institute for Primate Research, Göttingen, Germany,

${ }^{6}$ Department Anthropology/Sociobiology, University of Göttingen, Göttingen, Germany
\end{abstract}

Social influence is distributed unequally between males and females in many mammalian societies. In human societies, gender inequality is particularly evident in access to leadership positions. Understanding why women historically and cross-culturally have tended to be under-represented as leaders within human groups and organizations represents a paradox because we lack evidence that women leaders consistently perform worse than men. We also know that women exercise overt influence in collective group-decisions within small-scale human societies, and that female leadership is pervasive in particular contexts across non-human mammalian societies. Here, we offer a transdisciplinary perspective on this female leadership paradox. Synthesis of social science and biological literatures suggests that females and males, on average, differ in why and how they compete for access to political leadership in mixed-gender groups. These differences are influenced by sexual selection and are moderated by socioecological variation across development and, particularly in human societies, by culturally transmitted norms and institutions. The interplay of these forces contributes to the emergence of female leaders within and across species. Furthermore, females may regularly exercise influence on group decisions in less conspicuous ways and different domains than males, and these underappreciated forms of leadership require more study. We offer a comprehensive framework for studying inequality between females and males in access to leadership positions, and we discuss the implications of this approach for understanding the female leadership paradox and for redressing gender inequality in leadership in humans.

Keywords: leadership, gender, hierarchy, evolution, ecology, mammals, cooperation, collective decision-making

\section{INTRODUCTION}

Across all contemporary industrialized societies, women remain underrepresented in boardrooms and governments, holding fewer than $6 \%$ of CEO positions at S\&P 500 companies (Thomas, 2018) and fewer than $5 \%$ of national political leadership positions in the world. While this gender gap has been narrowing (Geiger and Kent, 2017; Bartleby, 2019), the challenges women face in climbing the corporate and political ladder remain substantial (Ryan and Haslam, 2005; Marshall et al., 2017; Kirsch, 2018). A male bias in top positions of leadership is a near cross-cultural universal: in a 
large sample of historical and contemporary non-industrial societies, formal political leadership positions were exclusive to men in approximately $88 \%$. Among the $10 \%$ of societies in which women did occupy leadership positions they were either less numerous or less powerful than their male counterparts (Whyte, 1978). Why have women been less likely to make it to the top ranks in politics, business, science, and religion, whether cross-culturally or historically? This is a paradox given that there is no consistent evidence that women make worse leaders in terms of their traits (Eagly et al., 2003; Post, 2015; Yang et al., 2019), women exercise considerable political influence in many small-scale, more egalitarian human societies (Leacock, 1978; Wiessner, 2005; von Rueden et al., 2018), and female leadership is pervasive, particularly in some contexts, across nonhuman mammalian societies, even in species where males tend to dominate females in dyadic competition (Smith et al., 2020). In our contribution to this inter-disciplinary research topic, we explore this female leadership paradox from multiple disciplinary perspectives. Furthermore, we unite these perspectives into a framework that helps explain variation in female and male leadership across and within species, including humans.

In the human social sciences, scholars have in general attempted to explain the gender gap in leadership principally in terms of proximate factors such as gender stereotypes, glass ceilings, and institutional sexism (Koenig et al., 2011; Matsa and Miller, 2011; Hideg and Shen, 2019). Other scholars have invoked evolutionary theory to suggest that evolved motivations contribute to but do not fully determine nor justify observed leadership patterns (Low, 1992; Smuts, 1995; von Rueden et al., 2018). An implication of such evolutionary approaches is that once we identify these evolved motivations, then we, as a cultural species, can make more informed decisions about how to remove obstacles for women leaders (Smith et al., 2020). Furthermore, evolutionary approaches that make comparisons among species suggest that the study of leadership in the social sciences is often narrowly defined (e.g., in terms of who is in charge), analyzed in specific domains (e.g., military, business, politics), restricted to narrow goals (e.g., conflict management), and restricted to a subset of societies [e.g., Western, educated, industrialized, rich and democratic (WEIRD)] (van Vugt and Ahuja, 2011). If we broaden the scope of leadership to not just include the more conspicuous forms of leadership (e.g., the CEO, the president, the priest), then we see much more evidence of females exercising influence in collective decision-making.

In general, we will argue that evolutionary theory, which predicts sex-specific yet environmentally contingent behavioral strategies (Clutton-Brock and Huchard, 2013b), can be complementary to traditional social science explanations of gender differences in leadership patterns. We define leaders as those individuals who have disproportionate influence, including decision-making power, on collective behavior (Pyritz et al., 2011b; Smith et al., 2016). It is important to emphasize that leadership should not be conflated with dominance (see next section), with the latter defined instead as the power to win fights or coerce others to gain priority of access in a resource hierarchy (deWaal, 1986; Hand, 1986; Van Vugt and Smith, 2019). Thus, whereas dominance refers to coercive influence within the group's resource hierarchy, leadership refers to influence within the group's decision-making processes and need not be coercive. Leadership can involve overt or more subtle forms of influence (e.g., direct intervention vs. example-setting), vary across individuals according to the context, and be distributed across group members or be concentrated in a single individual within a context (Glowacki and von Rueden, 2015; Smith et al., 2016; Smith and van Vugt, 2020). For example, in some non-human societies, leaders may actively break-up fights (e.g., prosocial policing by rhesus macaques; Beisner and McCowan, 2013) whereas in others leaders simply recruit followers by moving first (e.g., group travel to water by zebra; Fischhoff et al., 2007) or targeting a prey animal (e.g., group hunting by lions; Packer et al., 2001).

We use the term gender when referring to humans because of the influence of cultural norms on differences in behavior across men and women, and we use the term sex when referring more broadly to mammals. In fact, because gender is defined as the perceived sex (Money et al., 1955) or some other perceived identity related to sex, and we have no way of knowing whether and how animals may perceive themselves, the application of the gender concept in animals is inappropriate (Goymann and Brumm, 2018). Our focus on sex and gender differences is not meant to obscure the comparatively much larger variation for most behaviors observed within sexes and genders (Archer, 2019; Hyde et al., 2019), nor is it meant to argue that sex and gender are necessarily binary. Rather, we focus on behavior that does often vary moderately or considerably according to sex and gender categories. Some of the largest sex and gender differences are evident in particular cooperative and competitive behaviors (Zell et al., 2015; Archer, 2019), which can be compared across species, may be tied in part to processes of sexual selection, and are frequent targets of cultural norms.

We focus our synthesis on two potential factors contributing to observed gender differences in access to leadership in humans: (i) women and men tend to differ in how they cooperate and compete in the pursuit of leadership, and (ii) the perception by followers that women lack the "appropriate" leadership qualities. As we will argue, men and women, on average, often differ in what motivates the pursuit of leadership positions, and in strategies for acquiring leadership (e.g., direct vs. indirect competition, risk tolerance, differences in building and leveraging social connections). Moreover, studies at least in WEIRD societies show that potential followers often show implicit and explicit biases against overt forms of leadership by women (Rudman and Kilianski, 2000; Ridgeway, 2001; Simon and Hoyt, 2008; van Vugt and Spisak, 2008; Hoyt and Burnette, 2013). For instance, women may frequently be perceived as lacking in "agentic" traits (e.g., assertiveness, dominance) deemed necessary for good leadership; moreover, if women show agency they may receive negative reactions for violating gender stereotypes (Rudman and Phelan, 2008).

We construct a framework to explain these related phenomena, which integrates studies regarding the (a) evolutionary history (e.g., patterning across mammalian species), (b) human cultural history, (c) ecological function (e.g., fitness consequences), and (d) developmental origins 
of sex and gender differences in leadership. We divide our review into sections according to these levels of explanation. In addition, we emphasize throughout our review the role of socioecological variation across and within species as a source of sex and gender differences in competition for leadership, in the fitness consequences of such differences, and in their development. In humans, such socioecological variation includes culturally transmitted institutions and norms, for example those regarding gender divisions of labor and wealth inheritance. These institutions and norms influence and are influenced by gender differences in competition, as well as beliefs regarding "appropriate" leadership qualities and even what defines leadership. Our framework distinguishes direct effects of sexual selection on men and women's motivations and strategies, from indirect effects of sexually selected traits in terms of their contribution to (but neither determination nor justification of) cultural transmission of institutions and norms delineating rights and expectations by gender (Eagly and Karau, 2002). By identifying broad patterns across human and non-human societies as well as convergences between evolutionary and traditional social science theories, our framework provides a comprehensive and powerful explanation of sex and gender disparities in leadership. Furthermore, as we discuss at the end of our review, such a more comprehensive framework has unique implications for redressing gender inequality in access to leadership positions for humans.

\section{EVOLUTIONARY ORIGINS OF SEX DIFFERENCES IN LEADERSHIP}

A comparative perspective offers insights into what is universal and what is variable in terms of leader emergence according to sex, as well as the ancestral states and evolutionary transitions that account for what is universal and what is variable (Smith et al., 2016, 2020; Kappeler, 2017; Brosnan, 2018; Kappeler et al., 2019). Whereas power (French and Raven, 1959), dominance (Bass and Bass, 2009) and status (Cheng et al., 2010) are often used interchangeably to describe human behavior, this can be confusing from a comparative perspective (Van Vugt and Smith, 2019). Across species, individuals that influence collective decisions can be also high-ranking in the dominance hierarchy, as in the handful of mammals for which females are socially dominant to males (Smith et al., 2020). In mammals, female dominance is rare, but when it does occur, it is typically mediated by a larger body size and strength in females relative to males (Kappeler, 1993; Lewis, 2018; Smith and van Vugt, 2020). For biologists, dominance describes an individual's ability to gain priority of access to resources by winning dyadic fights with another individual (deWaal, 1986; Drews, 1993). In some species, individuals can also enhance access to resources via coalitional support (Harcourt and de Waal, 1992; Smith et al., 2010; Bissonnette et al., 2015). Importantly, however, leaders are neither necessarily always dominants nor vice versa (Fichtel et al., 2011; Van Vugt and Smith, 2019; Smith and van Vugt, 2020). The same is true of the relationship between leadership and sources of social status distinct from dominance, such as leverage (Lewis, 2002) or prestige (Henrich and Gil-White, 2001; Cheng et al., 2010). Thus, leadership, dominance, and other forms of social status require conceptual separation in studies of human and/or mammalian behavior (Henrich and Gil-White, 2001; Conradt and List, 2009).

Focusing on leadership within a broad cross-species perspective yields at least four novel insights. First, leadership is heterogeneous: leadership emerges in multiple contexts, including group movement, subsistence/foraging, within-group conflict resolution, and between-group interactions (Smith et al., 2016). In non-human mammals, the emergence of leaders in these contexts is typically more achievement-based (e.g., based on a leader's actions, age or strength) compared to human societies (Smith et al., 2016) where inheritance of wealth, formal titles, or social identities like race and gender often determine leadership (Garfield et al., 2019). However, inherited rank based on kinship contributes to leader emergence in those non-human mammals for which leaders may also tend to be of high dominance rank (Harcourt and de Waal, 1992; Smith et al., 2010), and some human societies, particularly most observed hunter-gatherers, lack leadership inheritance (Garfield et al., 2019). Leadership also varies in its distribution across group members. In non-human societies, leadership is often distributed among multiple individuals (Strandburg-Peshkin et al., 2016, 2018). That is, collective behavior is initiated and coordinated by several individuals even in groups with either steep or flat dominance hierarchies, such as those of baboons and some lemurs, respectively (Trillmich et al., 2004; King et al., 2008; Pyritz et al., 2011a). A fundamental difference between leadership in human and non-human societies is that, in humans, a centralized leader (or leaders) typically assign(s) tasks to different individuals to achieve a collective goal. In this case, followers share common intentions to produce an explicitly managed good. In contrast, non-human group movements and other collective behaviors emerge from individual behavioral decisions, often without explicit coordination by leaders (Couzin and Krause, 2003; Willems et al., 2015; Koch et al., 2016a,b; Willems, 2016).

Second, sex-biased leadership across mammalian societies is infrequent. Year-round permanent association of males and females occurs in only about a third of all mammalian species; non-human primates being a notable exception with about 70\% of species forming bisexual groups (Van Schaik and Kappeler, 1997). Moreover, males and females in permanently bisexual groups tend to establish minimally overlapping dominance hierarchies and/or interact primarily with members of the same sex, as seen for example across all major primate radiations (Fedigan and Baxter, 1984; de Waal and Luttrell, 1985; Kappeler, 1990a,b; Foerster et al., 2016), representing a potential constraint on the formation of cross-sex leader-follower relationships. Against this background, the uniqueness of gender-integrated decision-making hierarchies within the groups and organizations of human societies requires explicit acknowledgment in future studies of gender biases in leadership. Competition for leadership in mixed-gender groups can exacerbate gender inequality in access to overt leadership positions, because of gender stereotypes 
that portray women as less leader-like than men (Hegstrom and Griffith, 1992; Chen and Houser, 2019).

Third, sex-typical leadership roles in mammalian societies can vary by relevant socioecological context (Smith et al., 2020). In general, sex-specific fitness incentives contribute to patterns of leadership with a tendency for females to take the lead in contexts that affect the group's safety and ability to locate resources (see Figure 1), and a tendency for males to contribute more in contexts related to securing reproductive opportunities such as in between-group conflicts. However, there is much variation within and across species that complicates these sex-specific tendencies, as we discuss in the section on ecological functions of sex differences in leadership.

Fourth, sex differences in life history decisions (e.g., patterns of dispersal and reproduction) for male and female mammals can also have downstream consequences for social behaviors related to leadership. Since females in most mammalian societies are philopatric, they form kin-based coalitions more than males, who typically disperse from their natal group
(Wrangham, 1980; Kappeler and Van Schaik, 2002; Smith, 2014; Smith et al., 2017). In chimpanzees and bonobos, however, these sex roles are reversed, theoretically advantaging male (vs. female) coalition building through kin-selected benefits. Female bonobos nonetheless build coalitions with non-kin, providing an important role in internal peacekeeping and other aspects of group decision-making (Surbeck et al., 2011; Tokuyama and Furuichi, 2016). Female philopatry also provides female elders greater opportunities to use specialized ecological knowledge that benefits followers, particularly in species with exceptional longevity such as elephants or orcas (McComb et al., 2001; Brent et al., 2015). In humans, the evolution of unique life history traits created new opportunities and constraints for gender-specific leadership. Decreased inter-birth intervals and longer juvenile periods in concert with biparental care and a skill-intensive foraging niche promoted gender division of labor within extended families (Kaplan et al., 2009; Alger et al., 2020). The relative contribution of men and women to the diet, as well as gender
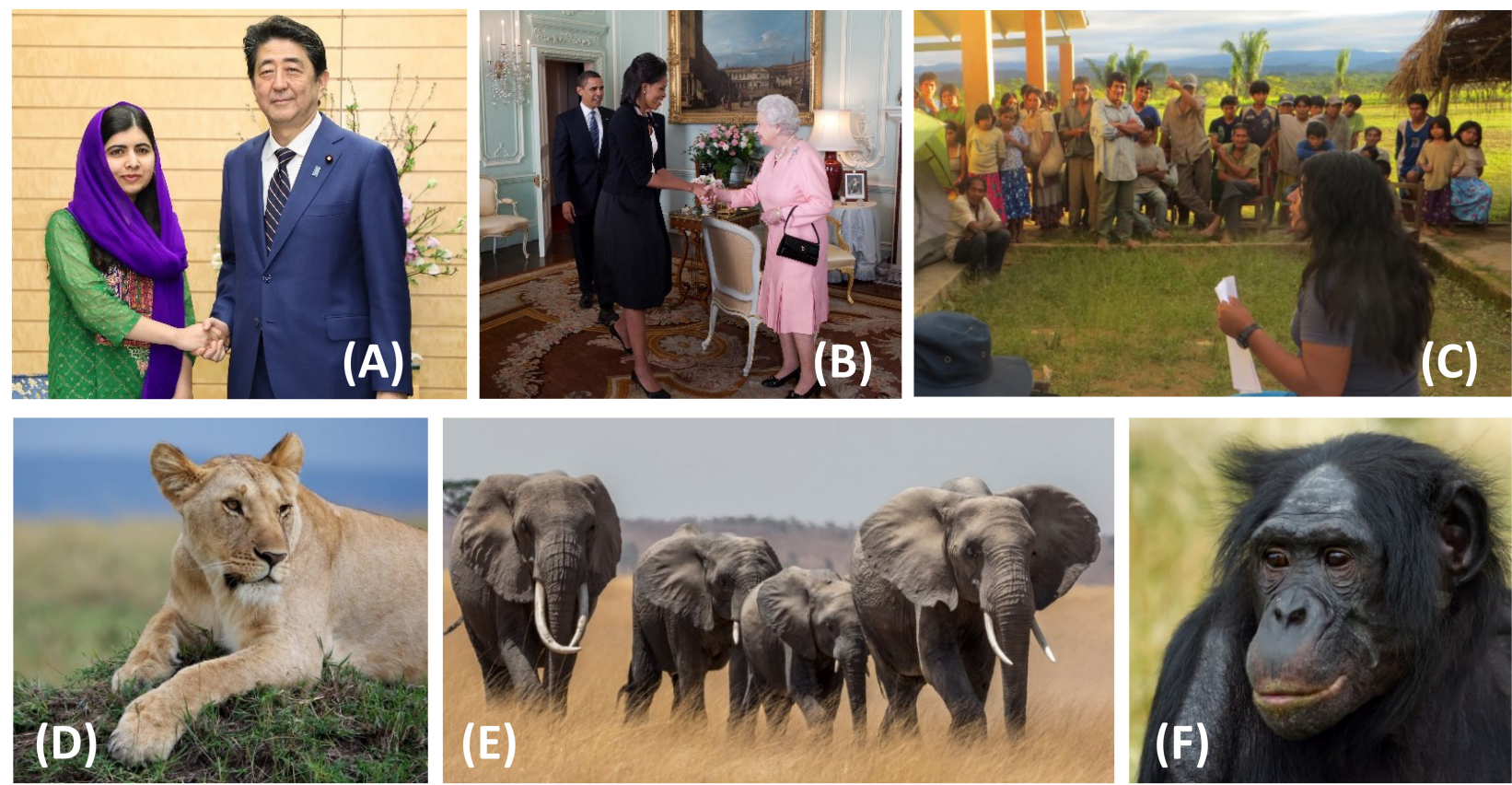

FIGURE 1 | Female leadership across mammalian societies. Women influence collective decisions in a variety of ways, as illustrated by (A) Malala Yousafzai (Pakistani activist for female education) shaking hands with Shinzô Abe (former Prime Minister of Japan), (B) Michelle Obama (first African American first lady of the United States and advocate for equity and inclusion) and Her Majesty, Elizabeth, II (Queen of the United Kingdom, a position inherited as the first born to King George VI and Queen Elizabeth), and (C) Agustina Bani of the Tsimané (leading discussion aimed to improve health outcomes in her Bolivian community). Among non-human mammals, strong female leadership is particularly well understood for eight species (Smith et al., 2020). Three of these species (not shown here) live in female-dominated societies: spotted hyenas (Boydston et al., 2001; Smith et al., 2010, 2015), ring-tailed lemurs (Nakamichi and Koyama, 1997; Sauther et al., 1999) and black-and-white ruffed lemurs (Morland, 1991; Overdorff et al., 2005). In all three species, females are at least as large or larger and stronger than males, suggesting a role for body size and fighting ability in promoting access to overt forms of female leadership. However, other societies promote female access to leadership through perhaps less overt forms, such as female cooperation; for example, (D) African lionesses lead in cooperative hunting and protection of offspring (Packer et al., 2001) and (F) female bonobos join forces to resolve tension and within-group conflict (deWaal, 1995; Furuichi, 2011; Tokuyama and Furuichi, 2016). Finally, females with specialized knowledge may emerge as leaders, as occurs in (E) African elephants for which the female matriarch serves as a repository of knowledge, leading group travel (McComb et al., 2001; Wittemyer and Getz, 2007) as well as in bonobos (Tokuyama and Furuichi, 2017) and killer whales (also not shown here; Foster et al., 2012; Brent et al., 2015). Just as in human societies, multiple pathways to female leadership exist in the natural world and these examples help to uncover the diverse and often underappreciated ways that females exert influence on collective behavior. (Photos by S. Richards, R. Bergstrom, Phôs Graphé, P. Souza, and P. Hooper with permission or part of the public domain). 
specialization in particular forms of food production, vary across observed hunter-gatherers according to habitat seasonality and other ecological factors (Marlowe, 2007), but in general women tend to engage in significantly more direct childcare (Kramer, 2010). To the extent aspects of gendered division of labor afford men more opportunity for broad-based social networking and wealth accrual within and across communities, it can make male-biased leadership beyond the household more likely (von Rueden et al., 2018), as we explain in subsequent sections.

\section{HISTORY OF GENDER INEQUALITY IN HUMAN SOCIETIES}

Although the comparative perspective offers insights into sex differences in leadership access and preferences across the mammalian lineage, examination of the unparalleled intraspecific variation in human social systems is also crucial for explaining the origin and diversity of human leadership (Table 1). An appreciation of human social and cultural diversity in space and time reveals that many modern and historical forms and functions of human leadership are relatively recent features of human sociality. Humans spent more than $95 \%$ of their existence as hunter-gatherers (Marlowe, 2005). While the modal pattern for modern hunter-gatherers is residence in groups of $\sim 30$ individuals (Bird et al., 2019), social networks might expand to hundreds of individuals over a person's lifetime due to fluidity in residence, trading partners, and kinship (Layton et al., 2012; Bird et al., 2019). A minority of hunter-gatherers who occupied highly productive coastal or riparian environments were led by chiefs with some degree of coercive authority, and the frequency of such "complex" hunter-gatherer societies may have been significantly higher in the Pleistocene prior to expansion of agricultural practices in the Holocene (Singh and Glowacki, 2021). Nevertheless, the majority of modern huntergatherers, if not hunter-gatherers in general, were relatively egalitarian with high degrees of autonomy for individuals (Kelly, 2013).

Many factors contribute to human egalitarianism, including pair bonding between men and women that reduces mating competition (Gavrilets, 2012), the ability for individuals or families to "vote with their feet" in the event of conflict via flexible residence patterns that are neither strictly patrilocal or matrilocal (Marlowe, 2005), an ability to form coalitions against would-be dominants (Boehm, 1999), reliance upon difficult to acquire food (which motivates extensive cooperation within and among families; Kaplan et al., 2009; Smith et al., 2012), and prestige-driven cooperation dynamics in which status depends on cooperation with lower status group members (von Rueden et al., 2019). Leadership exists in even the most egalitarian societies, whereby certain individuals wield more influence than others in the course of group decision-making. However, group decision-making remains largely consensusbased (von Rueden et al., 2014; Garfield et al., 2019). Women regularly influence group decisions in hunter-gatherer and other small-scale subsistence societies (Leacock, 1978), particularly in domains such as marriage and residential decision-making (Dyble et al., 2015) and informal dispute resolution (RadcliffeBrown, 1948; Bowser and Patton, 2010). Women in smallscale societies are also often noted more than men for their public criticism of non-normative behavior (e.g., Wiessner, 2005; Lewis, 2014). The latter can be a means for women to use men to advance their political goals, by turning private knowledge into common knowledge that forces the community or kin group to act. In some small-scale societies, women assume political leadership within their own religious and political organizations, such as in many Aboriginal societies (Dudgeon and Bray, 2019). However, even in some of the most egalitarian hunter-gatherer societies, women have been described as on average less politically influential relative to men, or as less frequent organizers of meetings to coordinate camp-wide activities (Radcliffe-Brown, 1948; Lee, 1980; Collier and Rosaldo, 1981; Lewis, 2014).

How gender affects leader emergence, even in the most egalitarian human societies, is likely in part due to sexually selected differences in competition and cooperation (see next section), as well as their contribution to culturally transmitted and enforced gendered divisions of labor. The latter is often based around the pair bond: women are typically expected to perform more labor within the house and men more labor outside of it (von Rueden et al., 2018). Though variable crossculturally in its form and magnitude, gender division of labor is relatively ubiquitous across human societies. Anthropologists have long tied gender inequality in political influence in both small and large-scale societies to gendered divisions of labor, which may constrain women's networking within and between communities and accord men more opportunity to amass and control wealth (Leacock, 1978; Coontz and Henderson, 1986).

The incidence of coercive leadership - recently referred to as dominance style leadership (Cheng et al., 2013; Maner, 2017; Van Vugt and Smith, 2019) - ratcheted up with the Neolithic revolution, when peoples' main subsistence strategy shifted from nomadic foraging to sedentary agriculture (Table 1). Dominance style leaders exercise their influence on group decisions by inflicting (or threatening to inflict) costs on nonfollowers whereas prestige style leaders instead influence group decisions by conferring (or promising to confer) benefits on followers (Van Vugt and Smith, 2019). Agriculture increased the incidence of dominance style leadership due to effects of agricultural surplus on demographic change and wealth inequality. Agricultural surpluses fueled population growth through increased reproductive rates, creating demand for centralized leadership with coercive powers to quell conflict and coordinate large-scale cooperation such as in warfare or food production (Hooper et al., 2010; von Rueden, 2020). Once granted coercive powers, leaders could then expand them to their advantage (Powers and Lehmann, 2014). Furthermore, kin-based lineages that could monopolize the most productive land and generate more surplus production asserted exclusive rights to leadership, by controlling the labor of the less privileged (Mattison et al., 2016). Of course, dominance-style leadership in humans cannot rest on coercion 
TABLE 1 | Human social diversity in space and time contributing to leadership.

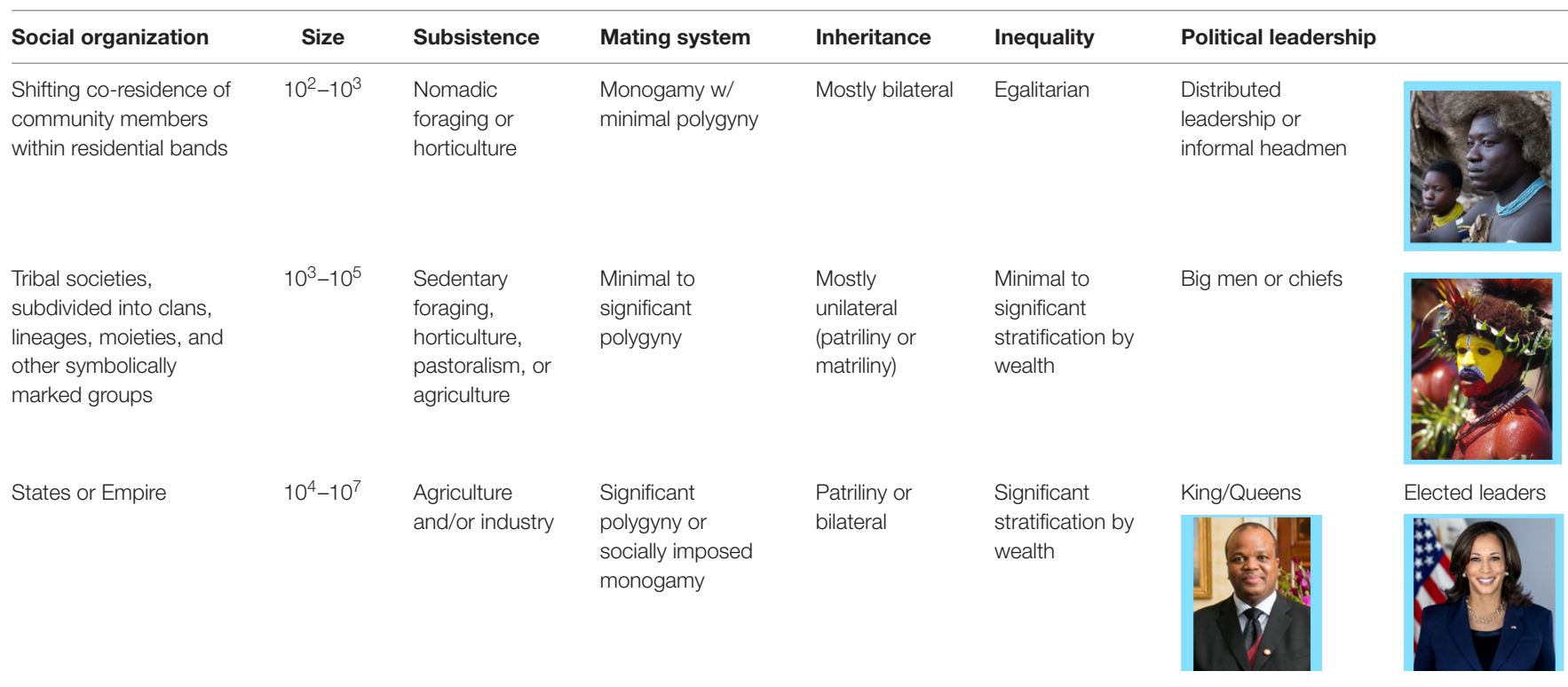

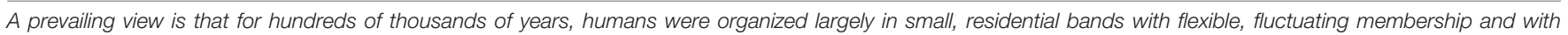

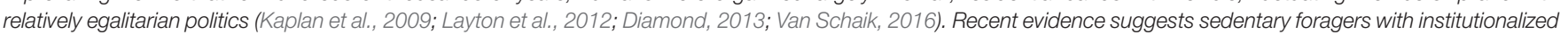

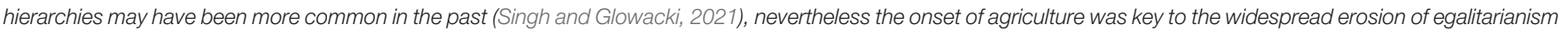

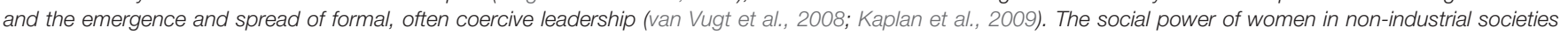

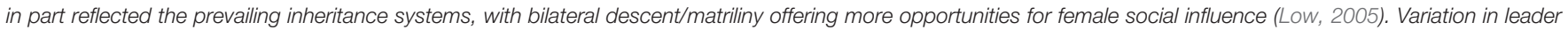

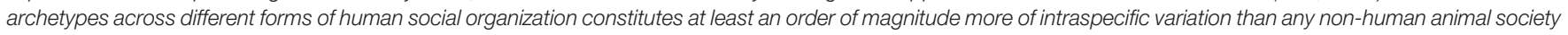

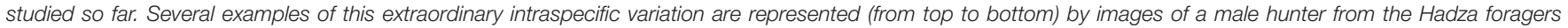

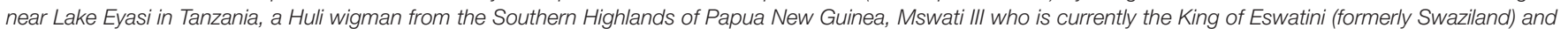

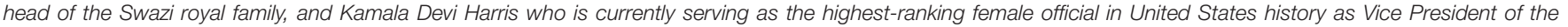
United States. Photos were taken by A. Peach, A.-J. Gros from The Yorck Project, A. Lucidon, and L. Jackson are public domain.

alone; autocrats must reward a large-enough coalition of powerful individuals to stave off revolution by the masses (Pandit et al., 2020).

Increasing inequality in political leadership brought with it increasing gender inequality. Monopolizable wealth likely increased men's motivation and opportunity to form large alliances with other men to control, defend, and compete for resources, enabling greater control over the reproductive decision-making of women (Smuts, 1995). Men's larger-scale alliance building was reinforced by increased threats and opportunities of inter-group conflict and warfare (Hayden et al., 1986; Rodseth, 2012) and by more restrictive gendered divisions of labor. Gender division of labor varies across societies according to local subsistence practices and economic opportunities (Starkweather et al., 2020). For example, the introduction of the plow made agricultural labor more strengthintensive and less compatible with childcare, thereby decreasing women's labor value outside of the home, decreasing women's bargaining power, and decreasing women's access to leadership (Alesina et al., 2011). Changing division of labor brought about new gender norms of what behavior is expected of men and women.

A minority of agricultural societies, particularly those with small to moderate amounts of material wealth, were matrilineal (i.e., descent traced from mother to daughter rather than father to son). Women may have most frequently acquired formal political leadership in those pre-industrial societies with matrilineal descent (Low, 1992). In the Iroquois confederation, for example, senior Iroquois women appointed and removed male chiefs and could veto their decisions, and Iroquois women arranged marriages and were as likely as men to be religious leaders (Brown, 1970). Men in matrilineal societies wield authority in terms of their relationship to the matriline, so mother's brothers nominally have the most authority in group decisions. However, the nominal authority of men in matrilineal societies may often contrast with real authority wielded by women, particularly at the household level (Mattison et al., 2019).

In contrast, patriliny exacerbated patriarchy, by increasing opportunities for large-scale male coalition building, distancing women from their kin, and entrenching male control over group decisions (Smuts, 1995; Wood and Eagly, 2002). Patriliny was more likely to emerge as societies became wealthier, in part because of the relationship between polygyny and wealth and thus the increased value to men of investing in their sons (Mattison et al., 2019). Political inequality ratcheted up further in early states, where a small elite spearheaded by a central ruler claimed a monopoly of force. While states have been more or less patriarchal, familial ties could promote a niche for women leaders, such as Queen Victoria (Schönpflug, 2010), to inherit powerful positions of leadership. Only recently have states tended to become less coercive, with multi-tiered leadership structures subject to approval of followers (Trouillot, 2001; van Vugt et al., 2008; Boehm, 2012; Diamond, 2013; Table 1). 


\section{ECOLOGICAL FUNCTIONS OF SEX DIFFERENCES IN LEADERSHIP}

\section{Sexual Selection and Sex-Specific Leadership}

Fitness costs and benefits associated with leadership decisions in animals are distinct from, but sometimes related to, those associated with dominance. For example, leaders within a group may influence group decisions to travel toward a food resource or to cooperatively capture prey, whereas dominance status determines an individual's priority of access to that food resource once it is located or acquired by a group. In the context of intergroup conflicts over territory boundaries, leaders influence when to initiate a fight and for how long (e.g., Boydston et al., 2001), whereas dominants determine who gains access to resources contained within a shared territory (e.g., Frank, 1986; Smith et al., 2008).

Because leadership is associated with individual costs and benefits, it is meaningful to ask whether these cost-benefit ratios vary systematically between the sexes across mammals. Sexual selection is expected to favor (1) sex differences in the pursuit of leadership in contexts for which the net benefits of leadership differ by sex. In addition, sexual selection can favor (2) sex differences in strategies of cooperation and competition, which can affect sex differences in the opportunity and motivation to lead in any context. A general prediction consistent with interpretations of sexual selection theory is that female mammals may be less motivated than males to pursue leadership that enhances mating opportunities at a cost to parental investment. According to the Bateman-Trivers paradigm (Bateman, 1948; Trivers, 1972), for example, males in many, but not all, species have a higher potential reproductive rate than females, primarily due to sex differences in parental investment (Kokko and Jennions, 2008; Clutton-Brock, 2017). Put differently, the number of reproductively available males tends to be greater than the number of reproductively available females, i.e., the operational sex ratio (OSR) is male-biased (Emlen and Oring, 1977). As a result, sexual selection related to direct competition for mates is expected to be stronger for males, whereas females are selected to maintain or increase total parental investment, such as via gestation and lactation in mammals (Trivers, 1972; CluttonBrock and Huchard, 2013a; Fromhage and Jennions, 2016). When females invest more in parental investment, female fitness is generally more limited by access to resources than is male fitness, whereas male fitness is generally more limited by access to fertile females. We will show below that these sex differences in resource limitation can also influence sex differences in leadership to in turn influence group decision-making.

While a strong consensus remains among biologists that female mammals in general and female primates in particular invest more than males in the energetically costly post-mating activities of gestation and lactation (Emlen and Oring, 1977; Kappeler and Van Schaik, 2002), the Bateman-Trivers paradigm has been heavily critiqued (Tang-Martínez, 2016); recent data (Gowaty et al., 2012, 2013) reveal that Bateman's (1948) measures of fitness variance were flawed and that the cost per gamete assumption of Trivers (1972) is problematic (Kokko and Jennions, 2008). Sex differences in post-mating investment can favor greater male than female intra-sexual competition for mates, but this may attenuate or, less frequently, reverse in response to high variation in male mate quality, male parental investment, or mating market factors that create female-biased sex ratios (Ralls, 1976; Kokko and Jennions, 2008; Brown et al., 2009; Rosvall, 2011). Furthermore, the effect of OSR on sexual selection can weaken as the OSR becomes increasingly biased, such as when an increasing number of rivals makes aggressive competition especially costly (Weir et al., 2011). And the effect of OSR on sexual selection can differ for different traits. Across animal species, higher OSR associates with increased mate guarding and aggression toward competitors but decreased courtship behavior (Weir et al., 2011).

Despite the aforementioned limitations, recent analytical models still confirm key insights of Bateman-Trivers (e.g., Fromhage and Jennions, 2016), and the general pattern of greater male investment in mate competition and greater female investment in parental investment continues to receive general empirical support across the animal kingdom (Janicke et al., 2016). Moreover, theoretical critiques of the Bateman-Trivers paradigm have helped explain the tremendous variation within and across species in sex-specific mate competition and parental investment (Clutton-Brock and Huchard, 2013b; Henshaw et al., 2019). Taken together, these differences in post-mating investment strategies can influence decisions regarding how, when, and why females versus males compete for opportunities to lead in collective decisions.

In terms of leadership, females can better meet their own and their offspring's energetic needs by leading (vs. following) members of their group to particular resources and by deciding how long to use them, as occurs in plains zebra (Fischhoff et al., 2007), bonobos (Tokuyama and Furuichi, 2017), muskoxen (Ihl and Bowyer, 2011), and lemurs (Pyritz et al., 2011a). Postmenopausal killer whales increase their own fitness by leading their sons to scarce resources (Brent et al., 2015). Males may also lead group foraging decisions, but perhaps less frequently to benefit offspring. Experiments with chacma baboons found that dominant males were most likely to lead groups to new food patches because they could monopolize the resources once obtained, and follower behavior was mediated by social ties to the dominant male (King et al., 2008). In muskoxen, although followers are generally most likely to follow adult females, males actively herd and block females to coordinate group movements during the breeding season (Ihl and Bowyer, 2011).

In the context of intergroup conflicts, studies of chimpanzees (Williams et al., 2004) and white-faced capuchins (Perry, 1996) suggest that border patrols and participation in intergroup conflicts are instead almost exclusively male activities; male participation increases access to mating opportunities (Wilson and Wrangham, 2003). In the context of intragroup conflict, observations of both chimpanzees and bonobos also suggest females tend to recruit coalition partners primarily to defend kin and friends against male aggression, whereas males tend to build coalitions primarily to compete for high rank and the mating opportunity it affords (Newton-Fisher, 2006; 
Tokuyama and Furuichi, 2016). However, a recent metanalysis of relevant primate studies revealed only weak support for the effect of sex on the frequency of aggression displayed toward outgroup individuals during intergroup encounters (Majolo et al., 2020). Moreover, the meta-analysis found significant variation in female participation in intergroup aggression across and within species (Majolo et al., 2020). In rare cases for which female mammals are the dominant sex, females also commonly lead intergroup conflicts and can be just as aggressive as males, as is seen in Verreaux's sifakas (Koch et al., 2016a) or ring-tailed lemurs (Nunn and Deaner, 2004). Moreover, in spotted hyenas, dominant females also influence group decisions by leading in intergroup conflicts significantly more often than males (Boydston et al., 2001). In vervet monkeys, females lead by initiating intergroup conflicts (to usurp food from other groups) and harass lower-ranking males to participate (Arseneau-Robar et al., 2017); females of this species, however, can be punished by dominant males for trying to escalate costly inter-group conflicts (Arseneau-Robar et al., 2018).

The costs of leading in different contexts also pattern sex differences in leadership. Costs of leadership in social mammals include enhanced predation risk (e.g., individuals that move first; Bumann et al., 1997) and synchronization costs (e.g., opportunity costs associated with building consensus; Conradt and Roper, 2005). Peacekeeping by disrupting dyadic fights, a central feature of leadership in various social mammals (Beisner and McCowan, 2013) has the potential to elicit retaliation. In humans, costs of leadership include risk of injury in warfare (Beckerman et al., 2009; Glowacki and Wrangham, 2013), opportunity costs including reduced attention to tasks in which one is not a leader (Piyapong et al., 2007), and greater reputational damage from failed collective action as well as retaliation as a result of conflict mediation decisions (von Rueden et al., 2014). From an evolutionary perspective, as leadership in violent contexts, such as in warfare or intragroup peacekeeping, increases the exposure of leaders to bodily injury or death, female leadership is likely constrained by the centrality of mothers to offspring reproduction and survival (Kruger and Nesse, 2006; Campbell, 2013 b). In order to minimize risk of injury, female primates in general may tend to engage in fights with greater selectivity than males (Clutton-Brock and Huchard, 2013b; Foerster et al., 2016).

\section{Sexual Selection in Humans and Gendered Divisions of Labor}

In non-industrial human societies, including egalitarian huntergatherers, men's leadership and other measures of social status (defined as a person's standing or importance in relation to other people within a society) tend to positively associate with various measures of reproductive success, particularly access to mates and fertility (von Rueden and Jaeggi, 2016). These effects are stronger in polygynous societies, where male leaders can marry multiple wives. In modern industrial societies, men's but not women's - income tends to associate with greater fertility, but the relationship may be driven by poor men who fail to reproduce more than by greater reproduction of men at the top of the social hierarchy (Nettle and Pollet, 2008; Stulp et al., 2016). Associations of social status and leadership with reproduction among women has received less attention in nonindustrial societies. However, existing studies suggest female status-seeking, in contrast to male status-seeking for leadership roles, may be motivated more by influencing decisions that improve child survival than by increasing mating opportunities (Alami et al., 2020). In general, available data suggest there tends to be greater variance in male compared to female reproduction within small-scale and large-scale human societies, though with considerable variation and in some instances a reversal of the gender difference (Brown et al., 2009; Betzig, 2012; Wilson et al., 2017). A comparison of mitochondrial and $Y$ sequences from diverse human populations suggests the tendency for greater variance in male relative to female reproduction dates to before the migration of modern humans from Africa (Lippold et al., 2014), with particularly large decreases in the number of males (but not females) who reproduced in the wake of agriculture 5000-7000 before the present (Karmin et al., 2015). This sex difference in reproductive variance over historical and evolutionary timescales, coupled with evidence of gendervarying effects of leadership on reproductive outcomes, suggests that women and men may in general have evolved somewhat divergent though overlapping motivations for acquiring access to leadership positions.

Why one gender should consistently be more likely to emerge as an overt leader in human, mixed-gender communitylevel politics requires additional explanation. Our integrative perspective focuses on two general causes of gender differences in access to political leadership in human societies: (i) women and men tend to differ in how they compete and cooperate in the pursuit of leadership, and (ii) followers - regardless of their own gender - are often biased against selecting female leaders. Our view suggests that not only do both factors contribute to shaping observed patterns of leader emergence, but they influence each other. Sexual selection shapes gender-specific competition strategies, which in turn influence (but neither determine nor justify) cultural transmission of institutions and norms, such as women's and men's specialization in different forms of labor and expectations regarding gender-appropriate behavior. Institutions and norms can then feedback on gender-specific competition strategies. Moreover, this bidirectional exchange is moderated by socio-ecological conditions (see Figure 2), which can exacerbate or minimize gender differences in competitive strategies and shape the kinds of gendered divisions of labor that emerge. We develop these ideas below.

Gender biases in leadership access or preferences may emerge as a by-product of selection on other functions. Sexual selection has likely contributed to men's larger body size and strength (Lassek and Gaulin, 2009), and may continue to do so (Stearns et al., 2012). Upper body strength in particular is quite dimorphic in humans (Lassek and Gaulin, 2009). Sexual selection may also have contributed to a greater tendency among men for physical or other risk-taking behaviors when pursuing leadership roles (Wilson and Daly, 1985; Mishra et al., 2017) and a greater preference among men for direct aggression in dyadic or collective competition (Archer, 1988; Van Vugt et al., 2007). The greater contribution to women's reproductive success 


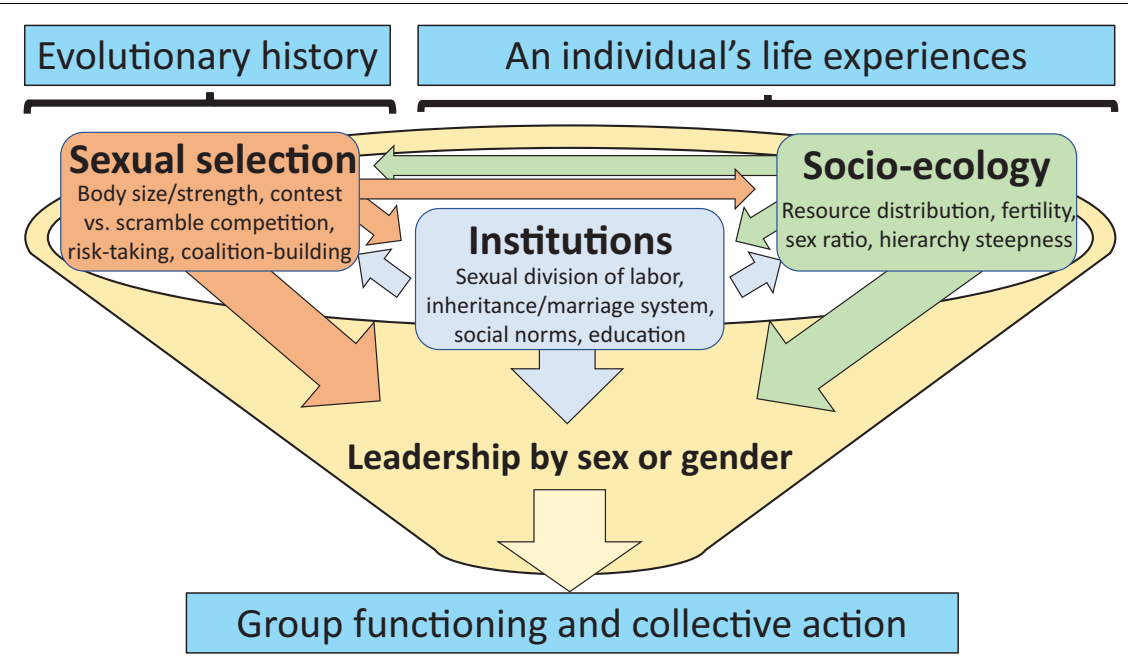

FIGURE 2 | Paths contributing to sex differences in leadership access and preferences. Sexual selection generates sex-specific traits, which interact with sociological circumstances over evolutionary history to generate institutional structures (humans) and traditions (non-human mammals). The effects of these processes on female access to leadership is mediated by learning over ontogeny, with consequences for group functioning and collective action. By recognizing these processes, as a cultural species, humans have the social flexibility and cognitive capacity to choose to confront and, to potentially overcome, sex-biased access to and preferences for leadership (Hrdy, 2009; Smith et al., 2020).

from parental investment, including gestation and lactation, may have made injury-causing activities riskier for women over human evolution (Campbell, 2013a). These risks may have contributed to a greater tendency among women to use indirect aggression, including gossip and social exclusion, in lieu of direct aggression to influence others (Hess and Hagen, 2006; Vaillancourt and Krems, 2018). Compared to women, men may have also experienced greater selection to engage in rapid, large-scale coalition-building, for purposes of often violent aggression (Wrangham and Peterson, 1996). Perhaps consistent with this claim is evidence, at least in WEIRD populations, that men can be more likely to build larger social networks with more "weak" ties (Vigil, 2007; Seabright, 2012; Friebel et al., 2017), prefer socializing in larger same-sex groups (David-Barrett et al., 2015; Benenson, 2019; Peperkoorn et al., 2020), and organize their groups hierarchically while revering other group members' competitiveness (Berdahl and Anderson, 2005; Watkins and Jones, 2016; Benenson and Abadzi, 2020). One general interpretation of the foregoing is that men and women may have evolved different, though overlapping, political strategies, where for men within-group cooperation may be more beneficial for enhancing between-group competition, while for women, within-group cooperation is likely to be more circumscribed and focused on recruiting sources of stable social support (Vandermassen, 2008; Mcdonald et al., 2012).

When they are present, these average gender differences in competition and cooperation may all have effects on gender differences in leader emergence. For example, average differences between women and men in risk-taking and preferred forms of competition may partly contribute to observations of a greater likelihood among men to self-promote and exaggerate competence in the pursuit of leadership (Chamorro-Premuzic, 2019), treat acquaintances or colleagues instrumentally to gain information, favors, or opportunities (Cullen-Lester et al., 2016), anticipate fewer risks to leadership (Sweet-Cushman, 2016), or be willing to make unilateral decisions on behalf of their group (Ertac and Gurdal, 2012). To the extent men more frequently socialize in large groups and build larger social networks with more "weak" ties, men may be advantaged in influencing the design of political institutions that regulate society and in accessing novel information or opportunities for ascending institutional hierarchies (Lindenlaub and Prummer, 2020).

Sexually selected strategies can also contribute to the evolution of follower psychology. For example, a contributing factor to favoritism for male leaders may be implicit or explicit associations between leader effectiveness and leaders' physical dominance. Experiments suggest group members show increased preference for physical dominance in leaders in contexts of negotiation or competition with other (out- groups; Lukaszewski et al., 2016; Laustsen and Petersen, 2017) or when conflict or free-riding is particularly threatening to within-group cooperation (Bøggild and Laustsen, 2016). Physically dominant leaders can pose their own threats to group members to the extent they lack other even more preferred traits in leaders such as expertise, fairness, and humility (Bøggild and Petersen, 2016), but the threat of group discoordination, dissolution, or extinction can loom larger. Even in democratic industrialized societies, references to body size are common to call attention to leaders' competence or lack thereof (van Vugt and Ahuja, 2011). For example, former United States president Trump's “broad-shouldered leadership" was a frequent refrain of his 2016 presidential campaign, which carried more than metaphorical meaning given the gender of his opponent (Chait, 2017).

Context-sensitive preferences for leaders with the capacity to wield physical dominance may have evolved for their functional value in the politics of small-scale societies lacking formal 
legal and political institutions. Among the Tsimané foragerhorticulturalists of Bolivia, a relatively egalitarian society, men's more overt influence over community politics is explained in part by their larger body size and strength, though to a lesser extent than men's greater exposure to formal education and greater number of cooperation partners (von Rueden et al., 2018). The body size effect may be due in part to perceived associations of body size with leader effectiveness (Kaplan et al., 2009; Blaker et al., 2013; von Rueden et al., 2014). Also, what predicts informal political influence in Tsimané women is similar to what predicts informal political influence in men: body size, access to education, social support, and their spouse's influence (von Rueden et al., 2018). Moreover, a study of recently settled huntergatherers in Ethiopia reached similar conclusions: gender is a weak predictor of community-level leadership once accounting for other predictors, and the traits that associate with men's and women's leadership are similar (Garfield and Hagen, 2020).

Furthermore, context can be critical for human gender differences in competition for leadership. Experiments have found that, cross-culturally, men tend to prefer even nonphysical competitive situations more than women (Bönte, 2015), including in a highly egalitarian society (Apicella and Dreber, 2015). However, some studies in matrilineal contexts find no gender difference in preference for competition (Gneezy et al., 2009). Still other studies find that women can become as competitive as men when competition directly benefits their children (Cassar et al., 2016), when top performers are given the opportunity to share their winnings (Cassar and Rigdon, 2021), or when performance rankings are inconspicuous (Schram et al., 2019). These disparate results might be partly explained by evolved differences across women and men in the costs of losing competitions (Benenson and Abadzi, 2020; Cassar and Rigdon, 2021). Women may have evolved greater motivation to avoid loser resentment because of risks to allo-maternal support, particularly where kin support is less available.

Even more indirectly, a contribution of sexual selection to traits such as body size, risk-taking, competitiveness, and coalition building can create asymmetries that affect roles men and women take in terms of gender division of labor. The latter was precipitated over human evolution by ecological change that made humans increasingly reliant on energetically rich but difficult to acquire hunted and gathered foods (Kaplan et al., 2009; Alger et al., 2020). Humans evolved shorter interbirth intervals and longer juvenile periods, in concert with increasing cooperation between pair-bonded sexual partners to care for and provision joint dependent offspring. How women and men have tended to contribute labor to the pair bond depends in part on sexually selected physiology and behavioral strategies. For instance, men tend to engage in more hunting compared to women across small-scale societies (Marlowe, 2005). Compared to other foraging strategies, hunting can be less compatible with pregnancy/lactation, is more compatible with men's greater tolerance for physical risk, can yield less consistent caloric returns for purposes of family provisioning, and provides more opportunities to show-off for building political influence and mate value (Hawkes and Bird, 2002; Gurven and Hill, 2009). The exceptions prove the rule: when women hunt in small-scale societies, it is typically with greater use of dogs and nets as opposed to upper-body strength intensive technology, and in pursuit of smaller, less riskily acquired game, which when shared is less conducive to showing-off but more for building cooperative support networks rather than gain mate value per se (Bird and Bird, 2008). Recent discovery of several early Holocene female skeletons associated with projectile point hunting technology raises the possibility that women engaged in more high-risk, large-game hunting in the past (Haas et al., 2020). If so, this must be reconciled with the infrequency of such hunting by women in recent small-scale societies.

Importantly, average differences in gender-specific behavior can emerge independent of coercion or discrimination and can then make it more likely that cultural norms stabilize gender-specific roles and punish deviance from them, reducing intra-gender behavioral variation (Micheletti et al., 2018). Furthermore, gendered divisions of labor and associated norms can feedback on the ability of women and men to pursue their optimal cooperation and competition strategies, such as by creating greater constraints on women's socializing beyond the household and on opportunities for acquiring wealth (von Rueden et al., 2018). Women in disparate small-scale societies may be more likely to gain political influence when they near menopause, perhaps because they have fewer childcare demands and are able to socialize more broadly within and beyond their communities (Brown, 1985). For example, women's group-level influence in the Mekranoti of the Brazilian Amazon negatively associated with their parenting demands (Werner, 1984), and there is evidence in the Tsimané that women's but not men's number of different cooperation partners negatively associates with number of dependent offspring (von Rueden et al., 2018). As previously described, introduction of the plow made agricultural labor more strength-intensive and less compatible with childcare, thereby decreasing women's labor value outside of the home, decreasing women's bargaining power, and decreasing women's access to leadership (Alesina et al., 2011). In another example, individuals from historically more pastoralist societies are more likely to promote restrictive norms concerning women's mobility (Becker, 2021). Econometric analyses suggest that men's fear of non-paternity due to periodic absence from their communities for herding or war initially promoted these restrictive gender norms (Becker, 2021). In other settings, economic opportunities may privilege women's work outside the home. Among Shodagor fisher-traders in Bangladesh, women travel to rural villages to trade with Muslim women, whose religion restricts their interaction with Shodagor men (Starkweather et al., 2020). In sum, gender division of labor likely acted as a key mechanism shaping the cross-cultural patterning of leadership by gender, phenomena that can only be fully understood through unification of evolutionary and social science approaches.

\section{DEVELOPMENTAL ORIGINS OF SEX DIFFERENCES IN LEADERSHIP}

A developmental perspective will help us to understand the ways that leadership roles are shaped across the lifespan by 
sexually selected motivations and by cultural transmission of norms and institutions. In general, juvenile mammals tend to initiate collective movements less often and are less often involved in leading intergroup conflicts than adults (Fichtel et al., 2011; Majolo et al., 2020). In fish, followers are most likely to use social information from large (female) rather than small (male) demonstrators when making collective foraging decisions (Duffy et al., 2009). However, despite increased documentation that animals are selective in what, when and whom they copy (Kendal et al., 2018), we know little about how leadership and followership emerge across ontogeny in non-human animals.

Because individuals with high social rank in the dominance hierarchy may also impose a disproportionate influence in collective decision-making in some mammalian species (Van Vugt and Smith, 2019), understanding the mechanisms of dominance rank acquisition is also relevant and informative in this context. In many Old World monkeys, female dominance rank is determined by maternal rank inheritance, whereby daughters adopt the ranks below their mother in an age-reversed order (Harcourt and de Waal, 1992), but virtually all adult males, who acquire their rank based on size and strength, dominate all females (Pereira, 1995). In spotted hyenas, maternal rank inheritance is also implemented via this same associative learning of repeated social support from others (Holekamp and Smale, 1991; Vullioud et al., 2019), and high-ranking adult females emerge most often as leaders in resolving withingroup conflicts, collective movements, and initiating intergroup conflicts (Boydston et al., 2001; Smith et al., 2010). In ring-tailed lemurs, female dominance over all males emerges spontaneously around puberty via male submission (Pereira, 1995). Thus, there exists great inter-specific diversity across mammals in the ways that socially powerful positions such as high dominance rank can be achieved. Similar patterns may apply to leadership emergence but will require explicit study.

In studies of children in WEIRD human societies, gender differences in social network attributes and group size preferences emerge early and perpetuate into adulthood (Rose and Rudolph, 2006; Benenson and Abadzi, 2020). For example, girls have been observed to have smaller same-gender play groups (Ladd, 1983; Ladd and Profilet, 1996) and less dense social networks than boys (Benenson, 1990, 1993). However, these trends can be strongly shaped by the preferences of a few popular youth who strongly favor boy companions; preferences for friends based on gender can be weak or absent for unpopular youth (Ladd, 1983). Furthermore, gender differences in social network size vary with age. A study of Europeans found that men have more social contacts than women, particularly in young adulthood, but then this gender difference reverses in middle age as the numbers of contacts for both genders precipitously decline and as reproductive priorities shift (Bhattacharya et al., 2016). In smaller-scale societies with higher fertility levels, women may tend to engage in more broad social networking as they approach middle age, perhaps because they have fewer dependent offspring in the household (Werner, 1984; Brown, 1985; von Rueden et al., 2018). In small-scale societies, children can be more likely to socialize in mixed-gender groups, which can weaken gender differences in behavior (Lew-Levy et al., 2019). A study of BaYaka and Hadza hunter-gatherer children finds that play within mixed-gender groups increases as the available pool of playmates decreases, and mixed-gender socialization may explain smaller gender differences in rough-and-tumble and other forms of play compared to WEIRD samples (Lew-Levy et al., 2019). Much more cross-cultural work is needed to determine variability in social networking and leadership emergence within networks by gender across the lifespan.

Gender differences in individual competitive behavior can also emerge early in development. Among young children, studies in WEIRD contexts find that boys tend to engage in more self-referencing behavior and are typically more likely to recognize and respect decision-making hierarchies within their groups, whereas girls are more likely to use indirect strategies, like ignoring, to compete for leadership positions (Hold-Cavell, 1996; Benenson and Abadzi, 2020). At older ages, the most popular children (both boys and girls) are the ones who apply tactics consistent with a combination of prestige and dominance leadership styles, though boys in general are more likely to pursue more purely coercive and aggressive tactics (Hawley, 2014). Gender differences in physical aggression and risk-taking may peak in late adolescence and young adulthood, when young men are most intensely competing to establish mate value (Wilson and Daly, 1985). Young women tend to compete more than men by emphasizing aspects of their physical appearance that signal residual reproductive value to potential mates (Cashdan, 1998; Campbell, 2013b).

Importantly, gender differences in social network building and in competition for leadership positions are shaped by norms of expected behavior (e.g., greater encouragement of boys to engage in team sports or girls to assist in childcare). Cross-culturally, manhood more than womanhood is described as something to be earned, and which can be gained or lost depending on display of competitive ability, skill, generosity, and leadership (Vandello et al., 2008). Societies that experience greater intergroup conflict are more likely to portray manhood as precarious in this way, and to impose costly initiation rites of passage on young men to test their manhood (Sosis et al., 2007) due to benefits to male coalition building in the context of war (Rodseth, 2012). These norms may also reflect evolved, gender-specific motivations, but, obviously, they are not determined by them (Henrich, 2015). For example, the more that prestigious political positions in society are monopolized by men, the more they may be likely to promote norms and build institutions that exacerbate and canalize average gender differences in competition, coalition-building, or even desire for political leadership.

Follower preferences in leaders also emerge early and can change over the lifespan. Even infants possess the ability to distinguish between bullies and leaders (Margoni et al., 2018). Harsh childhood conditions may favor long-lasting preferences for dominant-style leaders that rely upon the threat of punishment (Safra et al., 2017). Follower preferences may have effects on gender disparity in leadership well before aspiring leaders reach adulthood. In the United States, one study found that adolescent girls showed less ambition as political leaders than adolescent boys, likely in part because boys were more likely to 
be groomed and described as prospective leaders, by their family members, teachers, coaches, and other role models (Lawless and Fox, 2013). A recent study found no gender difference in interest in being a leader among 3- to 7-year-old children, but girls were less likely than boys to pick a same-gender peer as a leader (Mandalaywala and Rhodes, 2021). Like any social phenomenon, such favoritism toward boys is unlikely to be purely a social construction, but rather shaped by a complex interplay over evolutionary and historical timescales of evolved motivations with cultural transmission of institutions and norms, particularly a gendered division of labor.

\section{INTEGRATING EVOLUTIONARY AND SOCIAL SCIENCE PERSPECTIVES}

There are many benefits to viewing female leadership within a transdisciplinary perspective that integrates evolutionary and social science perspectives (Kappeler et al., 2019; Smith et al., 2020). Social role theories of gender (Eagly and Karau, 2002) are often contrasted with sexual selection approaches to gender differences, but we argue that these perspectives are not incompatible. More specifically, we focused on two outcomes of the mutual influence of evolutionary, ecological, and cultural factors, which often act to constrain female political leadership. That is, female competition and cooperation in pursuit of leadership can differ on average from that by males, and followers often demonstrate preferences for male over female leaders. As discussed above, evolved trait differences in humans can help explain the emergence and persistence of institutions and cultural norms, which enforce greater behavioral similarity within genders, affect opportunities for leadership by gender, and shape stereotypical conceptions of leadership. Emergence of particular gender norms and gender differences in leadership are further contingent on historical and cross-society variation, in subsistence, in inheritance systems, and in other factors. Studies in more egalitarian hunter-gatherers and other small-scale societies often report women exercising considerable leadership via inter-individual conflict resolution and criticism of nonnormative behavior, though women can be less likely than men to coordinate community-wide activities and men's voices can be more numerous during community political discussions (Collier and Rosaldo, 1981; von Rueden et al., 2018; Garfield et al., 2019). The agricultural revolution was a principal influence on historical increases in political inequality and exacerbation of patriarchy (Kaplan et al., 2009; Mattison et al., 2016; Van Vugt and Smith, 2019; von Rueden, 2020). This is partly due to the effects of agricultural innovation on gendered divisions of labor that further privileged men's social networking and access to wealth (Coontz and Henderson, 1986; Alesina et al., 2011) and to increased incentives for male coalition-building in the face of more frequent warfare (Hayden et al., 1986; Rodseth, 2012). While women were more likely to hold formal political positions in those agricultural societies with matrilineal descent (Low, 1992), women's leadership positions tended to be less numerous or less powerful than their male counterparts (Whyte, 1978). Men continue to hold more top positions of formal leadership in largescale, industrialized societies, but this gender gap has decreased in recent decades where ecological and economic conditions promoted declines in fertility and shifts in norms concerning women's education and labor force participation (Konner, 2015). There is evidence in WEIRD societies of large decreases in stereotypical associations of masculinity with competence and with leadership (Koenig et al., 2011; Eagly et al., 2019) and a decrease in preference for male over female bosses (Brenan, 2017). The balance of political power between women and men is shaped by the interplay of evolved gender differences, socio-ecology, and changing cultural institutions and norms (Low, 2005).

Our comparative perspective elucidates that overt forms of political decision-making are only one way in which individuals exert leadership in collective group decisions. In many mammalian species, females often emerge as leaders in the context of group movement for foraging or danger avoidance, less via active communication than by moving first (Smith et al., 2020). In small-scale human societies, men's politics may tend to be more public and aggrandizing but women frequently exert influence at the community level via less conspicuous means (Rosaldo, 1974). In a study of Tamil communities in south India, women were less likely than men to be identified as politically influential, partly because of less access to formal employment or material wealth. However, Tamil women may yield influence that is less visible through the more numerous support relationships they foster between community members (Power and Ready, 2018). In many human societies, men's historical monopolization of formal political leadership has contributed to associations of "appropriate" leader qualities with forms of competition more often preferred by men (Rudman and Phelan, 2008; Hoyt and Burnette, 2013). In addition to calling attention to gender inequality in overt forms of political leadership, scholars should devote more attention to more subtle forms of leadership displayed by women (and men) that can be as or more relevant to collective decision-making in human societies.

\section{SOME IMPLICATIONS FOR POLICY}

Increasing returns to education in a more globalized, serviceoriented economy may be increasing the rewards to women's preferred strategies to acquire leadership. Women now outpace men in educational attainment and life satisfaction in many of the most economically developed societies (Stoet and Geary, 2019). However, gender inequality in access to leadership positions in business, government, and other sectors persists. Consideration of the linkages between evolution and cultural norms provides a more comprehensive toolkit for dismantling contemporary gender inequality in access to top leadership roles. We offer five policy-relevant suggestions, which are neither the only ones that could follow from our integrated framework, nor necessarily what other evolutionary-informed approaches suggest.

First, we may be unlikely to generate gender equity in leadership largely by promoting behavioral similarity in women and men, such as simply encouraging women to "lean in" 
(Sandberg, 2013). Even in the absence of negative evaluations of women leaders who violate existing gender norms (Rudman and Phelan, 2008; Hoyt and Burnette, 2013), women and men, on average, may be motivated to pursue different leadership styles, with women, on average, adopting a more democratic, relational style (Eagly and Johnson, 1990; van Engen and Willemsen, 2004). A contribution of sexual selection to gender differences in competition and cooperation suggests average differences in leadership style are unlikely to universally disappear, but rather may be moderated by norms and institutional settings that change the gender-specific costs and benefits to particular forms of competition and cooperation (Gneezy et al., 2009; Cassar and Rigdon, 2021). Across societies, increased gender equity may even associate with increased (not decreased) average gender differences in many values and motivations (Falk and Hermle, 2018) - a phenomenon known as the gender equality paradox (Stoet and Geary, 2019, but also see: Breda et al., 2020). However, inter-individual variation independent of gender has and will likely continue to eclipse any average gender differences in predicting leader behavior (Bass and Stogdill, 1990).

Second, we can limit the extent to which certain gender differences privilege male leaders by calling attention to their limited or even negative impact on leader effectiveness. This includes men's greater tendency for self-promotion, overconfidence and exaggerating their competence, which helps elevate many unqualified men to positions of power (ChamorroPremuzic, 2019). To the extent men, more than women, prefer to socialize in larger same-sex groups (Low, 1992; David-Barrett et al., 2015; Benenson, 2019; Peperkoorn et al., 2020) and to build larger social networks comprised of many "weak" ties (Vigil, 2007; Seabright, 2012; Friebel et al., 2017), men may be unduly privileged in the pursuit of leadership, particularly in the mixed gender hierarchies of large organizations (van Vugt and Spisak, 2008; Cullen-Lester et al., 2016; Lindenlaub and Prummer, 2020). Effects of social networking on gender differences in leadership are exacerbated when leaders tend to be male and leaders in general prefer to hire and promote similar others (i.e., the "old boys network") (McDonald, 2011; Koch et al., 2015). We should scrutinize the extent to which organizations reward men's more than women's preferred forms of competition and cooperation (Cassar and Rigdon, 2021). Not just to redress inequality in leadership access, but also because organizational goals can suffer when competitive ("toxic") masculinity dominates an organizations' culture (Berdahl et al., 2018). We can also call attention to implicit preferences regarding leaders' physical formidability and dominance (Blaker et al., 2013), and the ways in which the media and politicians stoke fear of out-groups (Lopez, 2020) to draw out these preferences. Studies with WEIRD participants find male leaders are preferred during war whereas preferences for female leaders increase during times of peace (Van Vugt et al., 2007; Grabo and van Vugt, 2018; de Waal-Andrews and van Vugt, 2020).

Third, we can make use of other evolved motivations, particularly our tendency to emulate prestigious role models (Jiménez and Mesoudi, 2019), to chip away at cultural norms favoring men in positions of leadership. The more often that existing leaders, men or women, promote women as leaders, the more we normalize women as leaders and change stereotypical associations of leadership with masculinity. In a now famous study in India in which villages were randomly assigned a requirement to elect women as chief councilors, girls in the villages were subsequently more likely to aspire to higher education and politics (Beaman et al., 2012) and men acquired more positive views of women's leadership ability (Beaman et al., 2009). Institutional requirements for gender equity and inclusion can be transformational in shaping male and female preferences and female access to leadership.

Fourth, organizations can accelerate cultural change in gendered divisions of labor by making work more compatible with childcare and by adopting more charitable parental leave policies. Expansion of paternity leave can boost men's contribution to childcare and housework long after the period of paternity leave (Buenning, 2015; Patnaik, 2019). While women and men may differ on average in preferred work-childcare tradeoffs, such tradeoffs can be highly contingent on not only cultural norms and institutions but also on the biological changes that can accompany fatherhood. Parenthood can decrease men's desire to compete and advertise mate value as suggested by crosscultural evidence that reductions in testosterone can follow new fathers' direct involvement with their children (Gray et al., 2006; Gettler et al., 2011).

Fifth, societies can benefit by harnessing the diversity of leadership styles that come with a more equitable mix of female and male leaders. While average sex differences in preferences and motivations do not tend to be very large (Archer, 2019), they can still have important effects. In certain contexts, leader effectiveness may hinge more on risk-seeking, overt competitiveness, and creation of rigid hierarchical coalitions, on average favoring male leaders. In other contexts (Post, 2015), and some argue the majority of contexts (Eagly et al., 2003; Konner, 2015), leader effectiveness may hinge more on less direct forms of competition, risk aversion, and more empathy-driven forms of relationship building, on average favoring women leaders. For example, a study of gender quotas for firms in Norway found that more female directors decreased a firm's shorterterm financial performance but also decreased exposure to risk, with potentially longer-term positive consequences (Yang et al., 2019). In addition, women leaders can be more likely to prioritize issues like healthcare, welfare, and education (Funk and Philips, 2019; Hessami and da Fonseca, 2020) that advantage the most disadvantaged in society. Moreover, women's empowerment in general may be a key driver of transitions to greater democracy and transparency in government, and, in some cases, promote better outcomes during times of crisis (Wyndow and Mattes, 2013; Coscieme et al., 2020; Windsor et al., 2020).

\section{AUTHOR CONTRIBUTIONS}

All authors contributed the ideas and the writing of this manuscript. 


\section{ACKNOWLEDGMENTS}

We dedicate this manuscript to all of the past, present, and future female leaders in our lives. We thank the Institute for Advanced Study in Berlin (Wiko) for hosting a workshop in 2019, during which the ideas presented

\section{REFERENCES}

Alami, S., von Rueden, C., Seabright, E., Kraft, T. S., Blackwell, A. D., Stieglitz, J., et al. (2020). Mother's social status is associated with child health in a horticulturalist population. Proc. R. Soc. B Biol. Sci. 287:20192783. doi: 10.1098/ rspb. 2019.2783

Alesina, A., Giuliano, P., and Nunn, N. (2011). On the origins of gender roles: women and the plough. Inst. Study Labor Discuss. Pap. 5735, 1-43.

Alger, I., Hooper, P. L., Cox, D., Stieglitz, J., and Kaplan, H. S. (2020). Paternal provisioning results from ecological change. Proc. Natl. Acad. Sci. U.S.A. 117, 10746-10754. doi: 10.1073/pnas.1917166117

Apicella, C. L., and Dreber, A. (2015). Sex differences in competitiveness: huntergatherer women and girls compete less in gender-neutral and male-centric tasks. Adapt. Hum. Behav. Physiol. 1, 247-269. doi: 10.1007/s40750-014-0015-z

Archer, J. (1988). The Behavioral Biology of Aggression. Cambridge: Cambridge University Press.

Archer, J. (2019). The reality and evolutionary significance of human psychological sex differences. Biol. Rev. 94, 1381-1415.

Arseneau-Robar, T. J. M., Müller, E., Taucher, A. L., Van Schaik, C. P., Bshary, R., and Willems, E. P. (2018). Male monkeys use punishment and coercion to de-escalate costly intergroup fights. Proc. R. Soc. B Biol. Sci. 285:20172323. doi: $10.1098 / \mathrm{rspb} .2017 .2323$

Arseneau-Robar, T. J. M., Taucher, A. L., Schnider, A. B., van Schaik, C. P., and Willems, E. P. (2017). Intra- and interindividual differences in the costs and benefits of intergroup aggression in female vervet monkeys. Anim. Behav. 123, 129-137. doi: 10.1016/j.anbehav.2016.10.034

Bartleby (2019). A small step for women. Economist 62. Available online at: https:// www.economist.com/business/2019/03/09/a-small-step-for-women (accessed August 7, 2021).

Bass, B., and Bass, R. (2009). The Bass Handbook of Leadership: Theory, Research, and Managerial Applications. New York, NY: Free Press.

Bass, B., and Stogdill, R. (1990). Bass \& Stogdill's Handbook of Leadership: Theory, Research, and Managerial Applications. New York, NY: Free Press.

Bateman, A. J. (1948). Intra-sexual selection in Drosophila. Heredity 2, 349-368. doi: 10.1038/hdy.1948.21

Beaman, L., Chattopadhyay, R., Duflo, E., Pande, R., and Topalova, P. (2009). Powerful women: does exposure reduce bias? Q. J. Econ. 124, 1497-1540. doi: 10.1162/qjec.2009.124.4.1497

Beaman, L., Duflo, E., Pande, R., and Topalova, P. (2012). Female leadership raises aspirations and educational attainment for girls: a policy experiment in India. Science 335, 582-586. doi: 10.1126/science.1212382

Becker, A. (2021). On the Economic Origins of Restrictions on Women's Sexuality. CESifo Working Paper No. 7770. Available online at https://ssrn.com/abstract= 3432818 (accessed August 7, 2021)

Beckerman, S., Erickson, P. I., Yost, J., Regalado, J., Jaramillo, L., Sparks, C., et al. (2009). Life histories, blood revenge, and reproductive success among the Waorani of Ecuador. Proc. Natl. Acad. Sci. U.S.A. 106, 8134-8139. doi: 10.1073/pnas.0901431106

Beisner, B. A., and McCowan, B. (2013). Policing in nonhuman primates: partial interventions serve a prosocial conflict management function in rhesus macaques. PLoS One 8:e77369. doi: 10.1371/journal.pone.0077369

Benenson, J. F. (1990). Gender differences in social networks. J. Early Adolesc. 10, 472-495. doi: 10.1177/0272431690104004

Benenson, J. F. (1993). Greater preference among females than males for dyadic interaction in early childhood. Child Dev. 64, 544-555. doi: 10.2307/1131268

Benenson, J. F. (2019). Sex differences in human peer relationships: a primate'seye view. Curr. Dir. Psychol. Sci. 28, 124-130. doi: 10.1177/09637214188 12768 here were developed. The Meg Quigley Fellowship in Women, Gender and Sexuality Studies and the LettsVillard Endowed Professorship in the Natural Sciences at Mills College also supported JS. MV was supported by a Humboldt Research Award by the Alexander von Humboldt Foundation.

Benenson, J. F., and Abadzi, H. (2020). Contest versus scramble competition: sex differences in the quest for status. Curr. Opin. Psychol. 33, 62-68. doi: 10.1016/j.copsyc.2019.07.013

Berdahl, J., and Anderson, C. (2005). Men, women, and leadership centralization in groups over time. Gr. Dyn. Theory Res. Pract. 9, 45-57. doi: 10.1037/10892699.9.1.45

Berdahl, J. L., Glick, P., and Cooper, M. (2018). How masculinity contests undermine organizations, and what to do about it. Harv. Bus. Rev. Available online at: https://hbr.org/2018/11/how-masculinity-contests-undermineorganizations-and-what-to-do-about-it (accessed August 7, 2021).

Betzig, L. (2012). Means, variances, and ranges in reproductive success: comparative evidence. Evol. Hum. Behav. 33, 309-317. doi: 10.1016/j. evolhumbehav.2011.10.008

Bhattacharya, K., Ghosh, A., Monsivais, G., Dunbar, R., and Kaski, K. (2016). Sex differences in social focus across the life cycle in humans. R. Soc. Open Sci. 3:160097. doi: $10.1098 /$ rsos. 160097

Bird, D. W., Bird, R. B., Codding, B. F., and Zeanah, D. W. (2019). Variability in the organization and size of hunter-gatherer groups: foragers do not live in small-scale societies. J. Hum. Evol. 131, 96-108. doi: 10.1016/j.jhevol.2019. 03.005

Bird, R. B., and Bird, D. W. (2008). Why women hunt: risk and contemporary foraging in a western desert aboriginal community. Curr. Anthropol. 49, 655693. doi: $10.2307 / 20142695$

Bissonnette, A., Perry, S., Barrett, L., Mitani, J. C., Flinn, M., Gavrilets, S., et al. (2015). Coalitions in theory and reality: a review of pertinent variables and processes. Behaviour 152, 1-56. doi: 10.1163/1568539x-00003241

Blaker, N. M., Rompa, I., Dessing, I. H., Vriend, A. F., Herschberg, C., and van Vugt, M. (2013). The height leadership advantage in men and women: testing evolutionary psychology predictions about the perceptions of tall leaders. Gr. Process. Intergr. Relat. 16, 17-27. doi: 10.1177/1368430212437211

Boehm, C. (1999). Hierarchy in the Forest: The Evolution of Egalitarian Behavior. Cambridge, MA: Harvard University Press.

Boehm, C. (2012). Ancestral hierarchy and conflict. Science 336, 844-847. doi: $10.1126 /$ science. 1219961

Bøggild, T., and Laustsen, L. (2016). An intra-group perspective on leader preferences: different risks of exploitation shape preferences for leader facial dominance. Leadersh. Q. 27, 820-837. doi: 10.1016/j.leaqua.2016.09.003

Bøggild, T., and Petersen, M. B. (2016). "The evolved functions of procedural fairness: an adaptation for politics," in The Evolution of Morality, eds T. Shackelford and R. Hansen (Berlin: Springer International Publishing), 247276. doi: 10.1007/978-3-319-19671-8_12

Bönte, W. (2015). Gender differences in competitive preferences: new crosscountry empirical evidence. Appl. Econ. Lett. 22, 71-75. doi: 10.1080/13504851. 2014.927560

Bowser, B., and Patton, J. (2010). "Women's leadership: political alliance, economic resources, and reproductive success in the ecuadorian Amazon," in The Evolution of Leadership: Transitions in Decision Making from Small-scale to Middle-range Societies, eds K. J. V. Vaughn, J. W. Eerkens, and J. Kantner (Santa Fe: School for Advanced Research Press), 51-71.

Boydston, E. E., Morelli, T. L., and Holekamp, K. E. (2001). Sex differences in territorial behavior exhibited by the spotted hyena (Hyaenidae, Crocuta crocuta). Ethology 107, 369-385. doi: 10.1046/j.1439-0310.2001.00672.x

Breda, T., Jouini, E., Napp, C., and Thebault, G. (2020). Gender stereotypes can explain the gender-equality paradox. Proc. Natl. Acad. Sci. U.S.A. 117, 31063-31069. doi: 10.1073/pnas.2008704117

Brenan, N. (2017). Americans No Longer Prefer Male Boss to Female Boss. Gall. Poll. Available online at: https://news.gallup.com/poll/222425/americans- nolonger-prefermale-boss-female-boss.aspx (accessed August 7, 2021). 
Brent, L. J. N., Franks, D. W., Foster, E. A., Balcomb, K. C., Cant, M. A., and Croft, D. P. (2015). Ecological knowledge, leadership, and the evolution of menopause in killer whales. Curr. Biol. 25, 746-750. doi: 10.1016/j.cub.2015.01.037

Brosnan, S. F. (2018). Insights into human cooperation from comparative economics. Nat. Hum. Behav. 2, 432-434. doi: 10.1038/s41562-018-0383-7

Brown, J. (1985). "Introduction," in In Her Prime: A New View of Middle-Aged Women, ed. J. Brown (South Hadley: Bergin \& Garvey), 1-11. doi: 10.1093/ actrade/9780199589944.003.0001

Brown, J. K. (1970). Economic organization and the position of women among the Iroquois. Ethnohistory 17, 151-167. doi: 10.2307/481207

Brown, M., Laland, K., and Borgerhoff Mulder, M. (2009). Bateman's principles and human sex roles. Trends Ecol. Evol. 24, 297-304.

Buenning, M. (2015). What happens after the 'Daddy Months'? Fathers' involvement in paid work, childcare, and housework after taking parental leave in Germany. Eur. Sociol. Rev. 31:jcv072.

Bumann, D., Krause, J., and Rubenstein, D. (1997). Mortality risk of spatial positions in animal groups: the danger of being in the front. Behaviour 134, 1063-1076. doi: 10.1163/156853997x00403

Campbell, A. (2013a). A Mind of Her Own. Oxford: Oxford University Press.

Campbell, A. (2013b). The evolutionary psychology of women's aggression. Philos. Trans. R. Soc. B Biol. Sci. 368:20130078.

Cashdan, E. (1998). Are men more competitive than women? Br. J. Soc. Psychol. 37, 213-229. doi: 10.1111/j.2044-8309.1998.tb01166.x

Cassar, A., and Rigdon, M. L. (2021). Option to cooperate increases women's competitiveness and closes the gender gap. Evol. Hum. Behav. (in press).

Cassar, A., Wordofa, F., and Zhang, Y. J. (2016). Competing for the benefit of offspring eliminates the gender gap in competitiveness. Proc. Natl. Acad. Sci. U.S.A. 113, 5201-5205. doi: 10.1073/pnas.1520235113

Chait, J. (2017). 17 Times Mike Pence Praised Donald Trump's Shoulders. Intellegencer New York. Available online at: https://nymag.com/intelligencer/ 2017/08/12-times-mike-pence-praised-donald-trumps-shoulders.html (accessed August 22, 2020).

Chamorro-Premuzic, T. (2019). Why do so Many Incompetent Men Become Leaders?: (and How to Fix it). Cambridge: Harvard Business Review Press.

Chen, J., and Houser, D. (2019). When are women willing to lead? The effect of team gender composition and gendered tasks. Leadersh. Q. 30, 101340. doi: 10.1016/j.leaqua.2019.101340

Cheng, J. T., Tracy, J. L., Foulsham, T., Kingstone, A., and Henrich, J. (2013). Two ways to the top: evidence that dominance and prestige are distinct yet viable avenues to social rank and influence. J. Pers. Soc. Psychol. 104, 103-125. doi: $10.1037 / \mathrm{a} 0030398$

Cheng, J. T., Tracy, J. L., and Henrich, J. (2010). Pride, personality, and the evolutionary foundations of human social status. Evol. Hum. Behav. 31, 334347. doi: 10.1016/j.evolhumbehav.2010.02.004

Clutton-Brock, T. (2017). Reproductive competition and sexual selection. Philos. Trans. R. Soc. B Biol. Sci. 372:20160310.

Clutton-Brock, T., and Huchard, E. (2013a). Social competition and its consequences in female mammals. J. Zool. 289, 151-171. doi: 10.1111/jzo.12023

Clutton-Brock, T. H., and Huchard, E. (2013b). Social competition and selection in males and females. Philos. Trans. R. Soc. B Biol. Sci. 368:20130074. doi: 10.1098/rstb.2013.0074

Collier, J. F., and Rosaldo, M. Z. (1981). "Politics and gender in simple societies," in Sexual Meanings, eds S. B. Ortner and H. Whitehead (Cambridge: Cambridge University Press), 275-329.

Conradt, L., and List, C. (2009). Group decisions in humans and animals: a survey. Philos. Trans. R. Soc. B Biol. Sci. 364, 719-742. doi: 10.1098/rstb.2008.0276

Conradt, L., and Roper, T. J. (2005). Consensus decision making in animals. Trends Ecol. Evol. 20, 449-456. doi: 10.1016/j.tree.2005.05.008

Coontz, S., and Henderson, P. (1986). Women's Work, Men's Property: The Origins of Gender and Class. London: Verso.

Coscieme, L., Fioramonti, L., Mortensen, L. F., Pickett, K. E., Kubiszewski, I., Lovins, H., et al. (2020). Women in power: female leadership and public health outcomes during the COVID-19 pandemic. medRxiv [Preprint]. doi: 10.1101/ 2020.07.13.20152397

Couzin, I. D., and Krause, J. (2003). Self-organization and collective behavior in vertebrates. Adv. Study Behav. 32, 1-75. doi: 10.1016/s0065-3454(03) 01001-5
Cullen-Lester, K. L., Woehler, M. L., and Willburn, P. (2016). Network-based leadership development. J. Manag. Educ. 40, 321-358.

David-Barrett, T., Rotkirch, A., Carney, J., Behncke Izquierdo, I., Krems, J. A., Townley, D., et al. (2015). Women favour dyadic relationships, but men prefer clubs: cross-cultural evidence from social networking. PLoS One 10:e118329. doi: 10.1371/journal.pone.0118329

de Waal, F. B. M., and Luttrell, L. M. (1985). The formal hierarchy of rhesus macaques: an investigation of the bared-teeth display. Am. J. Primatol. 9, 73-85. doi: 10.1002/ajp.1350090202

de Waal-Andrews, W., and van Vugt, M. (2020). The triad model of follower needs: theory and review. Curr. Opin. Psychol. 33, 142-147. doi: 10.1016/j.copsyc.2019. 07.006

deWaal, F. B. M. (1986). The integration of dominance and social bonding in primates. Q. Rev. Biol. 61, 459-479. doi: 10.1086/415144

deWaal, F. B. M. (1995). Bonobo sex and society. Sci. Am. 272, 82-88. doi: 10.1038/scientificamerican0395-82

Diamond, J. (2013). The World Until Yesterday: What can We Learn from Traditional Societies?. New York, NY: Penguin Books.

Drews, C. (1993). The concept and definition of dominance in animal behaviour. Behaviour 125, 283-313. doi: 10.1163/156853993x00290

Dudgeon, P., and Bray, A. (2019). Indigenous relationality: women, kinship and the law. Genealogy 3:3020023.

Duffy, G. A., Pike, T. W., and Laland, K. N. (2009). Size-dependent directed social learning in nine-spined sticklebacks. Anim. Behav. 78, 371-375. doi: 10.1016/j. anbehav.2009.05.015

Dyble, M., Salali, G., Chaudhary, A., Page, A., Smith, D., Thompson, J., et al. (2015). Sex equality can explain the unique social structure of hunter-gatherer bands. Science 348, 796-798. doi: 10.1126/science.aaa5139

Eagly, A., Nater, C., Miller, D., Kaufmann, M., and Sczesny, S. (2019). Gender stereotypes have changed: a cross-temporal meta-analysis of U.S. public opinion polls from 1946 to 2018. Am. Psychol. 75, 301-315. doi: 10.1037/amp00 00494

Eagly, A. H., Johannesen-Schmidt, M. C., and Van Engen, M. L. (2003). Transformational, transactional, and laissez-faire leadership styles: a metaanalysis comparing women and men. Psychol. Bull. 129, 569-591. doi: 10.1037/ 0033-2909.129.4.569

Eagly, A. H., and Johnson, B. T. (1990). Gender and leadership style: a meta-analysis. Psychol. Bull. 108, 233-256. doi: 10.1037/0033-2909.108. 2.233

Eagly, A. H., and Karau, S. J. (2002). Role congruity theory of prejudice toward female leaders. Psychol. Rev. 109, 573-598. doi: 10.1037/0033-295x.109. 3.573

Emlen, S., and Oring, L. (1977). Ecology, sexual selection, and the evolution of mating systems. Science 197, 215-223. doi: 10.1126/science.327542

Ertac, S., and Gurdal, M. Y. (2012). Deciding to decide: gender, leadership and risktaking in groups. J. Econ. Behav. Organ. 83, 24-30. doi: 10.1016/j.jebo.2011. 06.009

Falk, A., and Hermle, J. (2018). Relationship of gender differences in preferences to economic development and gender equality. Science 362:eaas9899. doi: $10.1126 /$ science.aas 9899

Fedigan, L. M., and Baxter, M. J. (1984). Sex differences and social organization in free-ranging spider monkeys (Ateles geoffroyi). Primates 25, 279-294. doi: 10.1007/bf02382267

Fichtel, C., Pyritz, L., and Kappeler, P. M. (2011). "Coordination of group movements in non-human primates," in Coordination in Human and Primate Groups, eds M. Boos, M. Kolbe, P. M. Kappeler, and T. Ellwart (Berlin: Springer-Verlag), 37-56. doi: 10.1007/978-3-642-15355-6_3

Fischhoff, I. R., Sundaresan, S. R., Cordingley, J., Larkin, H. M., Sellier, M. J., and Rubenstein, D. I. (2007). Social relationships and reproductive state influence leadership roles in movements of plains zebra, Equus burchellii. Anim. Behav. 73, 825-831. doi: 10.1016/j.anbehav.2006.10.012

Foerster, S., Franz, M., Murray, C. M., Gilby, I. C., Feldblum, J. T., Walker, K. K., et al. (2016). Chimpanzee females queue but males compete for social status. Sci. Rep. 6, 1-11.

Foster, E. A., Franks, D. W., Mazzi, S., Darden, S. K., Balcomb, K. C., Ford, J. K. B., et al. (2012). Adaptive prolonged postreproductive life span in killer whales. Science 337:1313. doi: $10.1126 /$ science. 1224198 
Frank, L. G. (1986). Social organization of the spotted hyaena Crocuta crocuta. II. Dominance and reproduction. Anim. Behav. 34, 1510-1527. doi: 10.1016/ S0003-3472(86)80221-4

French, J. R. P., and Raven, B. (1959). "The bases of social power," in Classics of Organization, eds J. M. Shafritz, J. S. Ott, and Y. S. Jang (Boston, MA: Cengage Learning), 259-269.

Friebel, G., Lalanne, M., Richter, B., Schwardmann, P., and Seabright, P. (2017). Women Form Social Networks More Selectively and Less Opportunistically Than Men. SAFE Working Paper Series 168. Frankfurt: Leibniz Institute for Financial Research SAFE.

Fromhage, L., and Jennions, M. D. (2016). Coevolution of parental investment and sexually selected traits drives sex-role divergence. Nat. Commun. 7, 1-11. doi: 10.1007/s002650050508

Funk, K. D., and Philips, A. Q. (2019). Representative budgeting: women mayors and the composition of spending in local governments. Polit. Res. Q. 72, 19-33. doi: $10.1177 / 1065912918775237$

Furuichi, T. (2011). Female contributions to the peaceful nature of bonobo society. Evol. Anthropol. 20, 131-142. doi: 10.1002/evan.20308

Garfield, Z. H., and Hagen, E. H. (2020). Investigating evolutionary models of leadership among recently settled Ethiopian hunter-gatherers. Leadersh. Q. 31, 101290. doi: 10.1016/j.leaqua.2019.03.005

Garfield, Z. H., von Rueden, C., and Hagen, E. H. (2019). The evolutionary anthropology of political leadership. Leadersh. Q. 30, 59-80. doi: 10.1016/j. leaqua.2018.09.001

Gavrilets, S. (2012). Human origins and the transition from promiscuity to pairbonding. Proc. Natl. Acad. Sci. U.S.A. 109, 9923-9928. doi: 10.1073/pnas 1200717109

Geiger, A., and Kent, L. (2017). Number of Women Leaders Around the World has Grown, But They're Still a Small Group. Pew Res. Cent. Factank. Available online at: https://www.pewresearch.org/fact-tank/2017/03/08/women-leadersaround-the-world/ (accessed February 15, 2020).

Gettler, L., McDade, T., Feranil, A., and Kuzawa, C. (2011). Longitudinal evidence that fatherhood decreases testosterone in human males. Proc. Natl. Acad. Sci. U.S.A. 108, 16194-16199. doi: 10.1073/pnas.1105403108

Glowacki, L., and von Rueden, C. (2015). Leadership solves collective action problems in small-scale societies. Philos. Trans. R. Soc. B Biol. Sci. 370:20150010. doi: $10.1098 /$ rstb. 2015.0010

Glowacki, L., and Wrangham, R. W. (2013). The role of rewards in motivating participation in simple warfare. Hum. Nat. 24, 444-460. doi: 10.1007/s12110013-9178-8

Gneezy, U., Leonard, K. L., and List, J. A. (2009). Gender differences in competition: evidence from a matrilineal and a patriarchal society. Econometrica 77, 1637-1664. doi: 10.3982/ecta6690

Gowaty, P. A., Kim, Y. K., and Anderson, W. W. (2012). No evidence of sexual selection in a repetition of Bateman's classic study of Drosophila melanogaster. Proc. Natl. Acad. Sci. U.S.A. 109, 11740-11745. doi: 10.1073/pnas.1207851109

Gowaty, P. A., Kim, Y. K., and Anderson, W. W. (2013). Mendel's law reveals fatal flaws in Bateman's 1948 study of mating and fitness. Fly 7, 28-38. doi: 10.4161/fly.23505

Goymann, W., and Brumm, H. (2018). Let's talk about sex - not gender. Bioessays 40:1800030. doi: 10.1002/bies.201800030

Grabo, A., and van Vugt, M. (2018). Voting for a male warrior or female peacekeeper? Testing the evolutionary contingency hypothesis in the 2016 U.S. presidential elections. Evol. Psychol. 16, 1-9. doi: 10.1007/978-3-319-16999-6_ 645-1

Gray, P., Yang, C., and Pope, H. (2006). Fathers have lower salivary testosterone levels than unmarried men and married non-fathers in Beijing, China. Proc. $R$. Soc. B 273, 333-339. doi: 10.1098/rspb.2005.3311

Gurven, M., and Hill, K. (2009). Why do men hunt? A reevaluation of "Man the Hunter" and the sexual division of labor. Curr. Anthropol. 50, 51-74. doi: $10.1086 / 595620$

Haas, R., Watson, J., Buonasera, T., Southon, J., Chen, J., Noe, S., et al. (2020). Female hunters of the early Americas. Sci. Adv. 6:eabd0310. doi: 10.1126/sciadv. abd 0310

Hand, J. L. (1986). Resolution of social conflicts: dominance, egalitarianism, spheres of dominance, and game theory. Q. Rev. Biol. 61, 201-220. doi: 10 . $1086 / 414899$
Harcourt, A. H., and de Waal, F. B. M. (1992). Coalitions and Alliances in Humans and Other Animals. Oxford: Oxford University Press.

Hawkes, K., and Bird, R. B. (2002). Showing off, handicap signaling, and the evolution of men's work. Evol. Anthropol. 11, 58-67. doi: 10.1002/evan.20005

Hawley, P. H. (2014). The duality of human nature: coercion and prosociality in youth's hierarchy ascension and social success. Curr. Dir. Psychol. Sci. 23, 433-438. doi: 10.1177/0963721414548417

Hayden, B., Deal, M., Cannon, A., and Casey, J. (1986). Ecological determinants of women's status among hunter/gatherers. Hum. Evol. 1, 449-473. doi: 10.1007/ bf02436620

Hegstrom, J. L., and Griffith, W. I. (1992). Dominance, sex, and leader emergence. Sex Roles 27, 209-220. doi: 10.1007/bf00289925

Henrich, J. (2015). The Secret of Our Success: How Culture Is Driving Human Evolution, Domesticating Our Species, and Making Us Smarter. Princeton: Princeton University Press.

Henrich, J., and Gil-White, F. J. (2001). The evolution of prestige: freely conferred deference as a mechanism for enhancing the benefits of cultural transmission. Evol. Hum. Behav. 22, 165-196. doi: 10.1016/s1090-5138(00)00071-4

Henshaw, J., Fromhage, L., and Jones, A. (2019). Sex roles and the evolution of parental care specialization. Proc. R. Soc. B 286:20191312. doi: 10.1098/rspb. 2019.1312

Hess, N., and Hagen, E. (2006). Sex differences in informational aggression: psychological evidence from young adults. Evol. Hum. Behav. 27, 231-245.

Hessami, Z., and da Fonseca, M. L. (2020). Female political representation and substantive effects on policies: a literature review. Eur. J. Polit. Econ. 63:101896. doi: 10.1016/j.ejpoleco.2020.101896

Hideg, I., and Shen, W. (2019). Why still so few? A theoretical model of the role of benevolent sexism and career support in the continued underrepresentation of women in leadership positions. J. Leadersh. Organ. Stud. 26, 287-303. doi: $10.1177 / 1548051819849006$

Hold-Cavell, B. C. L. (1996). "The ethological bases of status hierarchies," in Food and the Status Quest, eds P. Wiessner and W. Schiefenhövel (Providence: Berghahn Books), 19-31.

Holekamp, K. E., and Smale, L. (1991). Dominance acquisition during mammalian social development: the "inheritance" of maternal rank. Am. Zool. 31, 306-317. doi: $10.1093 / \mathrm{icb} / 31.2 .306$

Hooper, P. L., Kaplan, H. S., and Boone, J. L. (2010). A theory of leadership in human cooperative groups. J. Theor. Biol. 265, 633-646. doi: 10.1016/j.jtbi. 2010.05.034

Hoyt, C. L., and Burnette, J. L. (2013). Gender bias in leader evaluations: merging implicit theories and role congruity perspectives. Pers. Soc. Psychol. Bull. 39, 1306-1319. doi: 10.1177/0146167213493643

Hrdy, S. B. (2009). The Woman that Never Evolved, 2nd Edn, Cambridge, MA: Harvard University Press.

Hyde, J., Bigler, R., Joel, D., Tate, C., and van Anders, S. (2019). The future of sex and gender in psychology: five challenges to the gender binary. Am. Psychol. 74, 171-193. doi: 10.1037/amp0000307

Ihl, C., and Bowyer, R. T. (2011). Leadership in mixed-sex groups of muskoxen during the snow-free season. J. Mammal. 92, 819-827. doi: 10.1644/10-mamma- 109.1

Janicke, T., Häderer, I. K., Lajeunesse, M. J., and Anthes, N. (2016). Darwinian sex roles confirmed across the animal kingdom. Sci. Adv. 2:e1500983. doi: 10.1126/sciadv.1500983

Jiménez, ÁV., and Mesoudi, A. (2019). Prestige-biased social learning: current evidence and outstanding questions. Palgrave Commun. 5, 1-12.

Kaplan, H. S., Hooper, P. L., and Gurven, M. (2009). The evolutionary and ecological roots of human social organization. Philos. Trans. R. Soc. B Biol. Sci. 364, 3289-3299. doi: 10.1098/rstb.2009.0115

Kappeler, P. (1993). Female dominance in primates and other mammals. Perspect. Ethol. 10, 143-158.

Kappeler, P. M. (1990a). Female dominance in Lemur catta: more than just female feeding priority? Folia Primatol. 55, 92-95. doi: 10.1159/000156504

Kappeler, P. M. (1990b). Social status and scent-marking behaviour in Lemur catta. Anim. Behav. 40, 774-776. doi: 10.1016/s0003-3472(05)80706-7

Kappeler, P. M. (2017). Sex roles and adult sex ratios: insights from mammalian biology and consequences for primate behaviour. Philos. Trans. R. Soc. B Biol. Sci. 372:20160321. doi: 10.1098/rstb.2016.0321 
Kappeler, P. M., Fichtel, C., van Vugt, M., and Smith, J. E. (2019). Female leadership: a transdisciplinary perspective. Evol. Anthropol. 28, 160-163. doi: 10.1002/evan. 21783

Kappeler, P. M., and Van Schaik, C. P. (2002). Evolution of primate social systems. Int. J. Primatol. 23, 707-740.

Karmin, M., Saag, L., Vicente, M., Sayres, M. A. W., Järve, M., Talas, U. G., et al. (2015). A recent bottleneck of Y chromosome diversity coincides with a global change in culture. Genome Res. 25, 459-466.

Kelly, R. L. (2013). The Lifeways of Hunter-Gatherers: The Foraging Spectrum. Cambridge: Cambridge University Press.

Kendal, R. L., Boogert, N. J., Rendell, L., Laland, K. N., Webster, M., and Jones, P. L. (2018). Social learning strategies: bridge-building between fields. Trends Cogn. Sci. 22, 651-665. doi: 10.1016/j.tics.2018.04.003

King, A. J., Douglas, C. M. S., Huchard, E., Isaac, N. J. B., and Cowlishaw, G. (2008). Dominance and affiliation mediate despotism in a social primate. Curr. Biol. 18, 1833-1838. doi: 10.1016/j.cub.2008.10.048

Kirsch, A. (2018). The gender composition of corporate boards: a review and research agenda. Leadersh. Q. 29, 346-364. doi: 10.1016/j.leaqua.2017. 06.001

Koch, A., D’Mello, S., and Sackett, P. (2015). A meta-analysis of gender stereotypes and bias in experimental simulations of employment decision making. J. Appl. Psychol. 100, 128-161. doi: 10.1037/a0036734

Koch, F., Signer, J., Kappeler, P. M., and Fichtel, C. (2016a). Intergroup encounters in Verreaux's sifakas (Propithecus verreauxi): who fights and why? Behav. Ecol. Sociobiol. 70, 797-808. doi: 10.1007/s00265-016-2105-3

Koch, F., Signer, J., Kappeler, P. M., and Fichtel, C. (2016b). The role of the residence-effect on the outcome of intergroup encounters in Verreaux's sifakas. Sci. Rep. 6:28457.

Koenig, A. M., Eagly, A. H., Mitchell, A. A., and Ristikari, T. (2011). Are leader stereotypes masculine?: a meta-analysis of three research paradigms. Psychol. Bull. 137, 616-642. doi: 10.1037/a0023557

Kokko, H., and Jennions, M. D. (2008). Parental investment, sexual selection and sex ratios. J. Evol. Biol. 21, 919-948. doi: 10.1111/j.1420-9101.2008.01540.x

Konner, M. (2015). Women After all: SEX, Evolution, and the End of Male Supremacy. New York, NY: W.W. Norton and Company.

Kramer, K. (2010). Cooperative breeding and its significance to the demographic success of humans. Annu. Rev. Anthropol. 39, 417-436. doi: 10.1146/annurev. anthro.012809.105054

Kruger, D. J., and Nesse, R. M. (2006). An evolutionary life-history framework for understanding sex differences in human mortality rates. Hum. Nat. 17, 74-97. doi: 10.1007/s12110-006-1021-z

Ladd, G. W. (1983). Social networks of popular, average, and rejected children in school settings. Merrill. Palmer. Q. 29, 283-307.

Ladd, G. W., and Profilet, S. M. (1996). The child behavior scale: a teacher-report measure of young children's aggressive, withdrawn, and prosocial behaviors. Dev. Psychol. 32, 1008-1024. doi: 10.1037/0012-1649.32.6.1008

Lassek, W. D., and Gaulin, S. J. C. (2009). Costs and benefits of fat-free muscle mass in men: relationship to mating success, dietary requirements, and native immunity. Evol. Hum. Behav. 30, 322-328. doi: 10.1016/j.evolhumbehav.2009. 04.002

Laustsen, L., and Petersen, M. B. (2017). Perceived conflict and leader dominance: Individual and contextual factors behind preferences for dominant leaders. Polit. Psychol. 38, 1083-1101. doi: 10.1111/pops.12403

Lawless, J. L., and Fox, R. L. (2013). Girls Just Wanna not Run. Washington, DC: American University.

Layton, R., O’Hara, S., and Bilsborough, A. (2012). Antiquity and social functions of multilevel social organization among human hunter-gatherers. Int. J. Primatol. 33, 1215-1245. doi: 10.1007/s10764-012-9634-z

Leacock, E. (1978). Women's status in egalitarian society: implications for social evolution. Curr. Anthropol. 19, 247-275.

Lee, R. B. (1980). The?!Kung San: Men, Women and Work in a Foraging Society. Cambridge: Cambridge University Press.

Lewis, J. (2014). "Pygmy hunter-gatherer egalitarian social organization: the case of the Mbendjele BaYaka," in Congo Basin Hunter-Gatherers, ed. B. Hewlett (New Brunswick, NJ: Transaction Publishers), 219-244. doi: 10.4324/ 9780203789438-8

Lewis, R. J. (2002). Beyond dominance: the importance of leverage. Q. Rev. Biol. 77, 149-164. doi: $10.1086 / 343899$
Lewis, R. J. (2018). Female power in primates and the phenomenon of female dominance. Annu. Rev. Anthropol. 47, 533-551. doi: 10.1146/annurev-anthro102317-045958

Lew-Levy, S., Boyette, A., Crittenden, A., Hewlett, B., and Lamb, M. (2019). Gender-typed and gender-segregated play among Tanzanian Hadza and Congolese BaYaka hunter-gatherer children and adolescents. Child Dev. 91, 1284-1301. doi: 10.1111/cdev.13306

Lindenlaub, I., and Prummer, A. (2020). Network structure and performance. Econ. J. 131, 851-898.

Lippold, S., Xu, H., Ko, A., Li, M., Renaud, G., Butthof, A., et al. (2014). Human paternal and maternal demographic histories: insights from high-resolution $\mathrm{Y}$ chromosome and mtDNA sequences. Investig. Genet. 5:13. doi: 10.1186/20412223-5-13

Lopez, A. C. (2020). Making 'my' problem 'our' problem: warfare as collective action, and the role of leader manipulation. Leadersh. Q. 31, 101294. doi: 10.1016/j.leaqua.2019.05.001

Low, B. S. (1992). Sex, coalitions, and politics in preindustrial societies. Polit. Life Sci. 11, 63-80. doi: 10.1017/s0730938400017214

Low, B. S. (2005). Women's lives there, here, then, now: a review of women's ecological and demographic constraints cross-culturally. Evol. Hum. Behav. 26, 64-87. doi: 10.1016/j.evolhumbehav.2004.08.011

Lukaszewski, A. W., Simmons, Z. L., Anderson, C., and Roney, J. R. (2016). The role of physical formidability in human social status allocation. J. Personal. Soc. Psychol. 110:385. doi: 10.1037/pspi0000042

Majolo, B., deBortoli Vizioli, A., Martínez-Íñigo, L., and Lehmann, J. (2020). Effect of group size and individual characteristics on intergroup encounters in primates. Int. J. Primatol. 41, 325-341. doi: 10.1007/s10764-019-00 119-5

Mandalaywala, T., and Rhodes, M. (2021). Gender stereotypes about leadership in early childhood. Psyarxiv [Preprint]. Available online at: https://psyarxiv.com/ ytsbn/ (accessed August 7, 2021).

Maner, J. K. (2017). Dominance and prestige: a tale of two hierarchies. Curr. Dir. Psychol. Sci. 26, 526-531. doi: 10.1177/0963721417714323

Margoni, F., Baillargeon, R., and Surian, L. (2018). Infants distinguish between leaders and bullies. Proc. Natl. Acad. Sci. U.S.A. 115, E8835-E8843.

Marlowe, F. (2005). Hunter-gatherers and human evolution. Evol. Anthropol. 14, 54-67.

Marlowe, R. (2007). Hunting and gathering: the human sexual division of foraging labor. Cross Cult. Res. 41, 170-195. doi: 10.1177/1069397106297529

Marshall, C., Johnson, M., and Edwards, T. (2017). "A feminist critical policy analysis of patriarchy in leadership," in Critical Approaches to Education Policy Analysis, eds M. D. Young and S. Diem (Cham: Springer), 131-150. doi: 10. 1007/978-3-319-39643-9_7

Matsa, D. A., and Miller, A. R. (2011). Chipping away at the glass ceiling: gender spillovers in corporate leadership. Am. Econ. Rev. 101, 635-639. doi: 10.1257/ aer.101.3.635

Mattison, S. M., Quinlan, R. J., and Hare, D. (2019). The expendable male hypothesis. Philos. Trans. R. Soc. B Biol. Sci. 374:20180080

Mattison, S. M., Smith, E. A., Shenk, M. K., and Cochrane, E. E. (2016). The evolution of inequality. Evol. Anthropol. Issues News Rev. 25, 184-199. doi: 10.1002/evan.21491

McComb, K., Moss, C., Durant, S. M., Baker, L., and Sayialel, S. (2001). Matriarchs as repositories of social knowledge in African elephants. Science 292, 491-494. doi: $10.1126 /$ science. 1057895

Mcdonald, M. M., Navarrete, C. D., and Van Vugt, M. (2012). Evolution and the psychology of intergroup conflict: the male warrior hypothesis. Philos. Trans. $R$. Soc. B Biol. Sci. 367, 670-679. doi: 10.1098/rstb.2011.0301

McDonald, S. (2011). What's in the "old boys" network? Accessing social capital in gendered and racialized networks. Soc. Netw. 33, 317-330. doi: 10.1016/j. socnet.2011.10.002

Micheletti, A. J. C., Ruxton, G. D., and Gardner, A. (2018). Why war is a man's game. Proc. R. Soc. B Biol. Sci. 285:20180975.

Mishra, S., Barclay, P., and Sparks, A. (2017). The relative state model: integrating need-based and ability-based pathways to risk-taking. Personal. Soc. Psychol. Rev. 21, 176-198. doi: 10.1177/1088868316644094

Money, D., Hamson, J., and Hamson, J. (1955). An examination of some basic sexual concepts: the evidence of human hermaphroditism. Bull. Johns Hopkins Hosp. 97, 301-319. 
Morland, H. S. (1991). Preliminary report on the social organization of ruffed lemurs (Varecia variegata variegata) in a Northeast Madagascar rain forest. Folia Primatol. 56, 157-161. doi: 10.1159/000156540

Nakamichi, M., and Koyama, N. (1997). Social relationships among ringtailed lemurs (Lemur catta) in two free-ranging troops at Berenty Reserve. Madagascar. Int. J. Primatol. 18, 73-93.

Nettle, D., and Pollet, T. V. (2008). Natural selection on male wealth in humans. Am. Nat. 172, 658-666. doi: 10.1086/591690

Newton-Fisher, N. (2006). Female coalitions against male aggression in wild chimpanzees of the Budongo Forest. Int. J. Primatol. 27, 1589-1599. doi: 10.1007/s10764-006-9087-3

Nunn, C., and Deaner, R. (2004). Patterns of participation and free riding in territorial conflicts among ringtailed lemurs (Lemur catta). Behav. Ecol. Sociobiol. 57, 50-61. doi: 10.1007/s00265-004-0830-5

Overdorff, D. J., Erhart, E. M., and Mutschler, T. (2005). Does female dominance facilitate feeding priority in black-and-white ruffed lemurs (Varecia variegata) in southeastern Madagascar? Am. J. Primatol. 66, 7-22. doi: 10.1002/ajp. 20125

Packer, C., Pusey, A. E., and Elberly, L. E. (2001). Egalitarianism in female African lions. Science 293, 690-693. doi: 10.1126/science.1062320

Pandit, S., Pradhan, G., and van Schaik, C. (2020). Why class formation occurs in humans but not among other primates. Hum. Nat. 31, 155-173. doi: 10.1007/ s12110-020-09370-9

Patnaik, A. (2019). Reserving time for Daddy: the consequences of fathers' quotas. J. Labor Econ. 37, 1009-1059. doi: 10.1086/703115

Peperkoorn, L., Becker, D., Balliet, D., Columbus, S., Molho, C., and van Lange, P. (2020). The prevalence of dyads in social life. PLoS One 15:e0244188. doi: 10.1371/journal.pone.0244188

Pereira, M. E. (1995). Development and social dominance among groupliving primates. Am. J. Primatol. 37, 143-175. doi: 10.1002/ajp.13503 70207

Perry, S. (1996). Intergroup encounters in wild white-faced capuchins (Cebus capucinus). Int. J. Primatol. 17, 309-330. doi: 10.1007/bf02736624

Piyapong, C., Morrell, L. J., Croft, D. P., Dyer, J. R. G., Ioannou, C. C., and Krause, J. (2007). A cost of leadership in human groups. Ethology 113, 821-824. doi: $10.1111 / \mathrm{j} .1439-0310.2007 .01382 . \mathrm{x}$

Post, C. (2015). When is female leadership an advantage? Coordination requirements, team cohesion, and team interaction norms. J. Organ. Behav. 36, 1153-1175. doi: 10.1002/job.2031

Power, E., and Ready, E. (2018). Building bigness: reputation, prominence, and social capital in rural South India. Am. Anthropol. 120, 444-459. doi: 10.1111/ aman. 13100

Powers, S. T., and Lehmann, L. (2014). An evolutionary model explaining the Neolithic transition from egalitarianism to leadership and despotism. Proc. $R$. Soc. B Biol. Sci. 281:20141349. doi: 10.1098/rspb.2014.1349

Pyritz, L. W., Kappeler, P. M., and Fichtel, C. (2011a). Coordination of group movements in wild red-fronted lemurs (Eulemur rufifrons): processes and influence of ecological and reproductive seasonality. Int. J. Primatol. 32, 13251347. doi: 10.1007/s10764-011-9549-0

Pyritz, L. W., King, A. J., Sueur, C., and Fichtel, C. (2011b). Reaching a consensus: terminology and concepts used in coordination and decision-making research. Int. J. Primatol. 32, 1268-1278. doi: 10.1007/s10764-011-9524-9

Radcliffe-Brown, A. R. (1948). The Andaman Islanders. Glencoe, IL: The Free Press.

Ralls, K. (1976). Mammals in which females are larger than males. Q. Rev. Biol. 51, 245-276. doi: 10.1086/409310

Ridgeway, C. L. (2001). Gender, status, and leadership. J. Soc. Issues 57, 637-655.

Rodseth, L. (2012). From bachelor threat to fraternal security: male associations and modular organization in human societies. Int. J. Primatol. 33, 1194-1214. doi: 10.1007/s10764-012-9593-4

Rosaldo, M. (1974). "Woman, culture, and society: a theoretical overview," in Woman, Culture and Society, eds M. Rosaldo and L. Lamphere (Stanford: Stanford University Press), 17-43.

Rose, A. J., and Rudolph, K. D. (2006). A review of sex differences in peer relationship processes: potential trade-offs for the emotional and behavioral development of girls and boys. Psychol. Bull. 132, 98-131. doi: 10.1037/00332909.132.1.98

Rosvall, K. A. (2011). Intrasexual competition in females: evidence for sexual selection? Behav. Ecol. 22, 1131-1140. doi: 10.1093/beheco/arr106
Rudman, L. A., and Kilianski, S. E. (2000). Implicit and explicit attitudes toward female authority. Personal. Soc. Psychol. Bull. 26, 1315-1328. doi: 10.1177/ 0146167200263001

Rudman, L. A., and Phelan, J. E. (2008). Backlash effects for disconfirming gender stereotypes in organizations. Res. Organ. Behav. 28, 61-79. doi: 10.1016/j.riob. 2008.04.003

Ryan, M. K., and Haslam, S. A. (2005). The glass cliff: evidence that women are over-represented in precarious leadership positions. Br. J. Manag. 16, 81-90. doi: 10.1111/j.1467-8551.2005.00433.x

Safra, L., Algan, Y., Tecu, T., Grèzes, J., Baumard, N., and Chevallier, C. (2017). Childhood harshness predicts long-lasting leader preferences. Evol. Hum. Behav. 38, 645-651. doi: 10.1016/j.evolhumbehav.2017.05.001

Sandberg, S. (2013). Lean In: Women, Work and the Will to Lead. New York, NY: Knopf Doubleday Publishing Group.

Sauther, M. L., Sussman, R. W., and Gould, L. (1999). The socioecology of the ringtailed lemur: thirty-five years of research. Evol. Anthropol. 8, 120-132. doi: 10.1002/(sici)1520-6505(1999)8:4<120::aid-evan3>3.0.co;2-o

Schönpflug, D. (2010). Dynastic networks. Constitution 5:7.

Schram, A., Brandts, J., and Gërxhani, K. (2019). Social-status ranking: a hidden channel to gender inequality under competition. Exp. Econ. 22, 396-418. doi: 10.1007/s10683-018-9563-6

Seabright, P. (2012). The War of the Sexes: How Conflict and Cooperation have Shaped Men and Women from Prehistory to the Present. Princeton, NJ: Princeton University Press.

Simon, S., and Hoyt, C. L. (2008). Exploring the gender gap in support for a woman for president. Anal. Soc. Issues Public Policy 8, 157-181. doi: 10.1111/j.15302415.2008.00167.x

Singh, M., and Glowacki, L. (2021). Human social organization during the Late Pleistocene: beyond the nomadic-egalitarian model. EcoEvoRxiv [Preprint]. doi: 10.32942/osf.io/vusye

Smith, J. E. (2014). Hamilton's legacy: kinship, cooperation and social tolerance in mammalian groups. Anim. Behav. 92, 291-304. doi: 10.1016/j.anbehav.2014. 02.029

Smith, J. E., Estrada, J. R., Richards, H. R., Dawes, S. E., Mitsos, K., and Holekamp, K. E. (2015). Collective movements, leadership and consensus costs at reunions in spotted hyaenas. Anim. Behav. 105, 187-200. doi: 10.1016/j.anbehav.2015. 04.023

Smith, J. E., Gavrilets, S., Mulder, M. B., Hooper, P. L., Mouden, C. E. L., Nettle, D., et al. (2016). Leadership in mammalian societies: emergence, distribution, power, and payoff. Trends Ecol. Evol. 31, 54-66. doi: 10.1016/j.tree.2015. 09.013

Smith, J. E., Kolowski, J. M., Graham, K. E., Dawes, S. E., and Holekamp, K. E. (2008). Social and ecological determinants of fission-fusion dynamics in the spotted hyaena. Anim. Behav. 76, 619-636. doi: 10.1016/j.anbehav.2008.05.001

Smith, J. E., Lacey, E. A., and Hayes, L. D. (2017). "Sociality in non-primate mammals," in Comparative Social Evolution, ed. D. R. Rubenstein (Cambridge: Cambridge University Press), 284-319. doi: 10.1017/9781107338319.011

Smith, J. E., Ortiz, C. A., Buhbe, M. T., and van Vugt, M. (2020). Obstacles and opportunities for female leadership in mammalian societies: a comparative perspective. Leadersh. Q. 31, 101267. doi: 10.1016/j.leaqua.2018.09.005

Smith, J. E., Swanson, E. M., Reed, D., and Holekamp, K. E. (2012). Evolution of cooperation among mammalian carnivores and its relevance to hominin evolution. Curr. Anthropol. 53, S436-S452. doi: 10.1086/667653

Smith, J. E., Van Horn, R. C., Powning, K. S., Cole, A. R., Graham, K. E., Memenis, S. K., et al. (2010). Evolutionary forces favoring intragroup coalitions among spotted hyenas and other animals. Behav. Ecol. 21, 284-303. doi: 10.1093/ beheco/arp181

Smith, J. E., and van Vugt, M. (2020). Leadership and status in mammalian societies: context matters. Trends Cogn. Sci. 24, 263-264. doi: 10.1016/j.tics. 2020.01.003

Smuts, B. (1995). The evolutionary origins of patriarchy. Hum. Nat. 6, 1-32. doi: 10.1007/978-3-319-16999-6_3186-1

Sosis, R., Kress, H. C., and Boster, J. S. (2007). Scars for war: evaluating alternative signaling explanations for cross-cultural variance in ritual costs. Evol. Hum. Behav. 28, 234-247. doi: 10.1016/j.evolhumbehav.2007.02.007

Starkweather, K. E., Shenk, M. K., and McElreath, R. (2020). Biological constraints and socioecological influences on women's pursuit of risk and the sexual division of labour. Evol. Hum. Sci. 2, 1-17. 
Stearns, S., Govindaraju, D., Ewbank, D., and Byars, S. (2012). Constraints on the coevolution of contemporary human males and females. Proc. R. Soc. B 279, 4836-4844. doi: 10.1098/rspb.2012.2024

Stoet, G., and Geary, D. C. (2019). A simplified approach to measuring national gender inequality. PLoS One 14:e0205349. doi: 10.1371/journal.pone.02 05349

Strandburg-Peshkin, A., Farine, D. R., Couzin, I. D., and Crofoot, M. C. (2016). Shared decision-making drives collective movement in wild baboons. Science 348, 1358-1361. doi: 10.1126/science.aaa5099

Strandburg-Peshkin, A., Papageorgiou, D., Margaret, C., and Farine, D. R. (2018). Inferring influence and leadership in moving animal groups. Philos. Trans. $R$. Soc. B 373:20170006. doi: 10.1098/rstb.2017.0006

Stulp, G., Sear, R., Schaffnit, S. B., Mills, M. C., and Barrett, L. (2016). The reproductive ecology of industrial societies, Part II: the association between wealth and fertility. Hum. Nat. 27, 445-470. doi: 10.1007/s12110-016-9 272-9

Surbeck, M., Mundry, R., and Hohmann, G. (2011). Mothers matter! Maternal support, dominance status and mating success in male bonobos (Pan paniscus). Proc. R. Soc. B 278, 590-598. doi: 10.1098/rspb.2010.1572

Sweet-Cushman, J. (2016). Gender, risk assessment, and political ambition. Polit. Life Sci. 35, 1-17. doi: 10.1017/pls.2016.13

Tang-Martínez, Z. (2016). Rethinking Bateman's principles: challenging persistent myths of sexually reluctant females and promiscuous males. J. Sex Res. 53, 532-559. doi: 10.1080/00224499.2016.1150938

Thomas, L. (2018). These are the Only Women CEOs Left Among SeP 500 Companies. CNBC. Available online at: www.cnbc.com/2018/08/06/these-arethe-only-women-ceos-left-among-sp-500-companies.html (accessed February $15,2020)$.

Tokuyama, N., and Furuichi, T. (2016). Do friends help each other? Patterns of female coalition formation in wild bonobos at Wamba. Anim. Behav. 119, 27-35. doi: 10.1016/j.anbehav.2016.06.021

Tokuyama, N., and Furuichi, T. (2017). Leadership of old females in collective departures in wild bonobos (Pan paniscus) at Wamba. Behav. Ecol. Sociobiol. 71:55.

Trillmich, J., Fichtel, C., and Kappeler, P. M. (2004). Coordination of group movements in wild Verreaux's sifakas (Propithecus verreauxi). Behaviour 141, 1103-1120. doi: 10.1163/1568539042664579

Trivers, R. (1972). "Parental investment and sexual selection," in Sexual Selection and the Descent of Man: 1871-1971, ed. B. Campbell (Chicago: Aldine), 136179. doi: $10.4324 / 9781315129266-7$

Trouillot, M. (2001). The anthropology of the state in the age of globalization. Curr. Anthropol. 42, 125-138. doi: 10.2307/3596474

Vaillancourt, T., and Krems, J. (2018). “An evolutionary psychological perspective on indirect aggression in girls and women," in The Development of Relational Aggression, eds S. Coyne and J. Ostrov (Oxford: Oxford University Press), 111-126.

van Engen, M., and Willemsen, T. (2004). Sex and leadership styles: a meta analysis of research published in the 1990s. Psychol. Rep. 94, 3-18. doi: 10.2466/pr0.94. 1.3- 18

Van Schaik, C. P. (2016). The Primate Origins of Human Nature. New York, NY: John Wiley \& Sons.

Van Schaik, C. P., and Kappeler, P. M. (1997). Infanticide risk and the evolution of male-female association in primates. Proc. R. Soc. Lond. Ser. B Biol. Sci. 264, 1687-1694. doi: 10.1098/rspb.1997.0234

van Vugt, M., and Ahuja, A. (2011). Naturally Selected: The Evolutionary Science of Leadership. New York, NY: Harper Business.

Van Vugt, M., De Cremer, D., and Janssen, D. P. (2007). Gender differences in cooperation and competition: the male-warrior hypothesis. Psychol. Sci. 18, 19-23. doi: 10.1111/j.1467-9280.2007.01842.x

van Vugt, M., Hogan, R., and Kaiser, R. B. (2008). Leadership, followership, and evolution: some lessons from the past. Am. Psychol. 63, 182-196. doi: 10.1037/ 0003-066x.63.3.182

Van Vugt, M., and Smith, J. E. (2019). A dual model of leadership and hierarchy: evolutionary synthesis. Trends Cogn. Sci. 23, 952-967. doi: 10.1016/j.tics.2019. 09.004

van Vugt, M., and Spisak, B. R. (2008). Sex differences in the emergence of leadership during competitions within and between groups. Psychol. Sci. 19, 854-858. doi: 10.1111/j.1467-9280.2008.02168.x
Vandello, J. A., Bosson, J. K., Cohen, D., Burnaford, R. M., and Weaver, J. R. (2008). Precarious manhood. J. Pers. Soc. Psychol. 95, 1325-1339.

Vandermassen, G. (2008). Can Darwinian feminism save female autonomy and leadership in egalitarian society? Sex Roles 59, 482-491. doi: 10.1007/s11199008-9478-3

Vigil, J. M. (2007). Asymmetries in the friendship preferences and social styles of men and women. Hum. Nat. 18, 143-161. doi: 10.1007/s12110-007-9003-3

von Rueden, C. R. (2020). Making and unmaking egalitarianism in small-scale human societies. Curr. Opin. Psychol. 33, 167-171. doi: 10.1016/j.copsyc.2019. 07.037

von Rueden, C. R., Alami, S., Kaplan, H., and Gurven, M. (2018). Sex differences in political leadership in an egalitarian society. Evol. Hum. Behav. 39, 402-411. doi: 10.1016/j.evolhumbehav.2018.03.005

von Rueden, C. R., Gurven, M., Kaplan, H., and Stieglitz, J. (2014). Leadership in an egalitarian society. Hum. Nat. 25, 538-566. doi: 10.1007/s12110-014-9213-4

von Rueden, C. R., and Jaeggi, A. V. (2016). Men's status and reproductive success in 33 nonindustrial societies: effects of subsistence, marriage system, and reproductive strategy. Proc. Natl. Acad. Sci. U.S.A. 113, 10824-10829. doi: $10.1073 /$ pnas. 1606800113

von Rueden, C. R., Redhead, D., O’Gorman, R., Kaplan, H., and Gurven, M. (2019). The dynamics of men's cooperation and social status in a small-scale society. Proc. R. Soc. B Biol. Sci. 286:20191367. doi: 10.1098/rspb.2019.1367

Vullioud, C., Davidian, E., Wachter, B., Rousset, F., Courtiol, A., and Höner, O. P. (2019). Social support drives female dominance in the spotted hyaena. Nat. Ecol. Evol. 3, 71-76. doi: 10.1038/s41559-018-0718-9

Watkins, C. D., and Jones, B. C. (2016). Competition-related factors directly influence preferences for facial cues of dominance in allies. Behav. Ecol. Sociobiol. 70, 2071-2079. doi: 10.1007/s00265-016-2211-2

Werner, J. (1984). Child care and influence among the Mekranoti of central Brazil. Sex Roles 10, 395-404. doi: 10.1007/bf00287556

Whyte, M. K. (1978). The Status of Women in Preindustrial Societies. Princeton, NJ: Princeton University Press.

Weir, L., Grant, J., and Hutchings, J. (2011). The influence of operational sex ratio on the intensity of competition for mate. Am. Nat. 177, 167-176. doi: $10.1086 / 657918$

Wiessner, P. (2005). Norm enforcement among the Ju/'hoansi Bushmen. Hum. Nat. 16, 115-145. doi: 10.1007/s12110-005-1000-9

Willems, E. P., Arseneau, T. J. M., Schleuning, X., and van Schaik, C. P. (2015). Communal range defence in primates as a public goods dilemma. Philos. Trans. R. Soc. B Biol. Sci. 370:20150003.

Willems, J. (2016). Building shared mental models of organizational effectiveness in leadership teams through team member exchange quality. Nonprofit Volunt. Sect. Q. 45, 568-592. doi: 10.1177/0899764015601244

Williams, J. M., Oehlert, G. W., Carlis, J. V., and Pusey, A. E. (2004). Why do male chimpanzees defend a group range? Anim. Behav. 68, 523-532. doi: 10.1016/j.anbehav.2003.09.015

Wilson, M., and Daly, M. (1985). Competitiveness, risk taking, and violence: the young male syndrome. Ethol. Sociobiol. 6, 59-73. doi: 10.1016/0162-3095(85) 90041-x

Wilson, M., Miller, C., and Crouse, K. (2017). Humans as a model species for sexual selection research. Proc. R. Soc. B 284:1320. doi: 10.1111/evo.12353

Wilson, M. L., and Wrangham, R. W. (2003). Intergroup relations in chimpanzees. Annu. Rev. Anthropol. 32, 363-392. doi: 10.1146/annurev.anthro.32.061002. 120046

Windsor, L. C., Reinhardt, G. Y., Windsor, A. J., Ostergard, R., Allen, S., Burns, C., et al. (2020). Gender in the time of COVID-19: evaluating national leadership and COVID-19 fatalities. PLoS One 15:e244531. doi: 10.1371/journal.pone. 0244531

Wittemyer, G., and Getz, W. M. (2007). Hierarchical dominance structure and social organization in African elephants, Loxodonta africana. Anim. Behav. 73, 671-681. doi: 10.1016/j.anbehav.2006.10.008

Wood, W., and Eagly, A. H. (2002). A cross-cultural analysis of the behavior of women and men: implications for the origins of sex differences. Psychol. Bull. 128, 699-727. doi: 10.1037/0033-2909.128.5.699

Wrangham, R., and Peterson, D. (1996). Demonic Males: Apes and the Origins of Human Violence. Boston: Houghton Mifflin.

Wrangham, R. W. (1980). An ecological model of female-bonded primate groups. Behaviour 75, 262-300. doi: 10.1163/156853980X00447 
Wyndow, P., and Mattes, E. (2013). Female empowerment as a core driver of democratic development: a dynamic panel model from 1980 to 2005 . World Dev. 52, 34-54. doi: 10.1016/j.worlddev.2013.06.004

Yang, P., Riepe, J., Moser, K., Pull, K., and Terjesen, S. (2019). Women directors, firm performance, and firm risk: a causal perspective. Leadersh. Q. 30, 101297. doi: 10.1016/j.leaqua.2019.05.004

Zell, E., Krizan, Z., and Teeter, S. (2015). Evaluating gender similarities and differences using metasynthesis. Am. Psychol. 70, 10-20. doi: 10.1037/a00 38208

Conflict of Interest: The authors declare that the research was conducted in the absence of any commercial or financial relationships that could be construed as a potential conflict of interest.
Publisher's Note: All claims expressed in this article are solely those of the authors and do not necessarily represent those of their affiliated organizations, or those of the publisher, the editors and the reviewers. Any product that may be evaluated in this article, or claim that may be made by its manufacturer, is not guaranteed or endorsed by the publisher.

Copyright (c) 2021 Smith, von Rueden, van Vugt, Fichtel and Kappeler. This is an open-access article distributed under the terms of the Creative Commons Attribution License (CC BY). The use, distribution or reproduction in other forums is permitted, provided the original author(s) and the copyright owner(s) are credited and that the original publication in this journal is cited, in accordance with accepted academic practice. No use, distribution or reproduction is permitted which does not comply with these terms. 